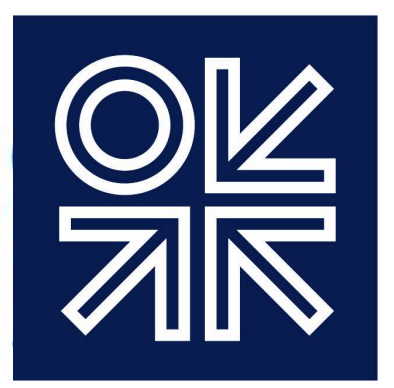

THE OXFORD

INSTITUTE

FOR ENERGY

STUDIES

\title{
Future European Gas Transmission Bottlenecks in Differing Supply and Demand Scenarios
}

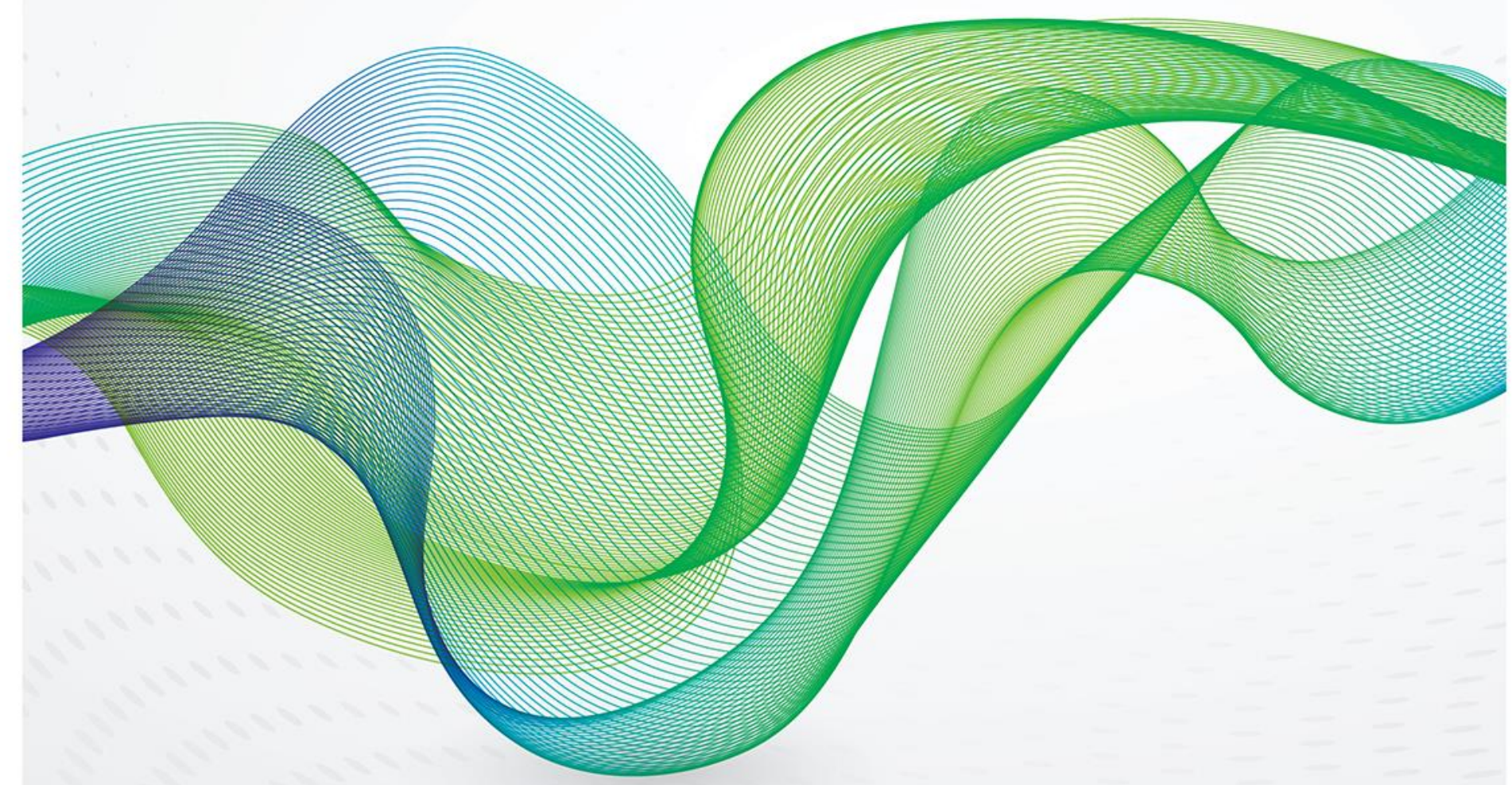



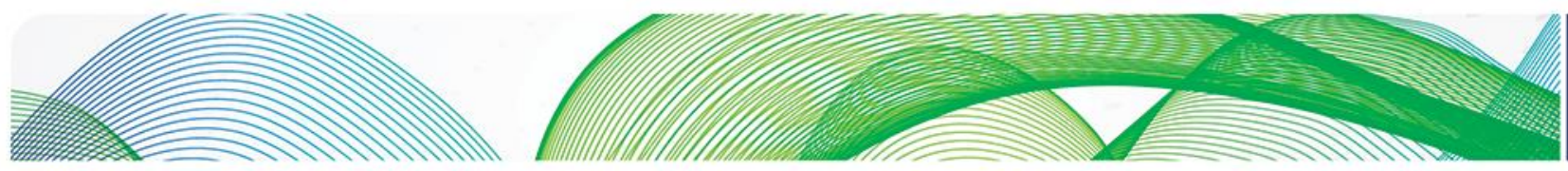

\section{잊조}

The contents of this paper are the authors' sole responsibility. They do not necessarily represent the views of the Oxford Institute for Energy Studies or any of its members.

\section{Oxford Institute for Energy Studies \& ewi Energy Research and Scenarios}

(Registered Charity, No. 286084)

This publication may be reproduced in part for educational or non-profit purposes without special permission from the copyright holder, provided acknowledgment of the source is made. No use of this publication may be made for resale or for any other commercial purpose whatsoever without prior permission in writing from the Oxford Institute for Energy Studies.

ISBN 978-1-78467-085-6 

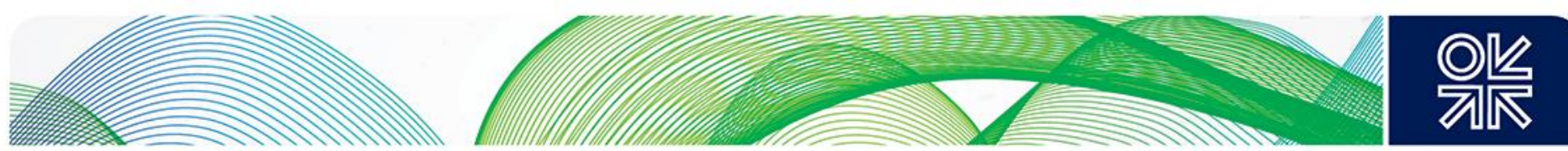

\section{Preface}

Annual consumption in the regional European gas market peaked in 2010 and by 2015 had declined by 15 per cent. While the retiral of coal and nuclear generation plant in the 2020 s may serve to support gas demand, the inexorable rise of state-supported renewables is expected to erode Europe's gas consumption in the power generation and subsequently the space heating and possibly industrial sectors in the longer term. In this context, it may seem strange to focus on transmission system bottlenecks in a regional market which having seen dramatic expansion since its inception in the late 1960 s has at best only modest growth potential.

The first clue lies in the papers published by Beatrice Petrovich which examined the price correlation of gas trading hubs across the European market from the mid-2000s. These suggested the design capacity and contractual relationships of the early transmission system perhaps lagged behind changing supply flow patterns and the responsiveness required to allow gas to flow freely in response to hub price supply signals. An earlier joint OIES - EWI paper examined historical manifestations of de-linked hub prices and by 'modelling history' - using the EWI TIGER model - related this to physical and contractual restrictions.

Projecting forward to 2030, this paper looks at how bottlenecks may change under two scenarios based on high and low cases for LNG and Russian pipeline gas imports respectively, in the context of modest European gas demand growth. Bottlenecks are examined both in terms of LNG and pipeline import capacity at the European border and at critical interconnector points within Europe.

This paper should be of interest at a strategic level for commercial players in the gas market and also to regulators and system operators charged with ensuring that future infrastructure is in place to facilitate pan-European traded markets against a background of changing supply patterns.

This paper is the product of excellent co-operation between OIES and ewi Energy Research and Scenarios.

Howard Rogers

Oxford May 2017 

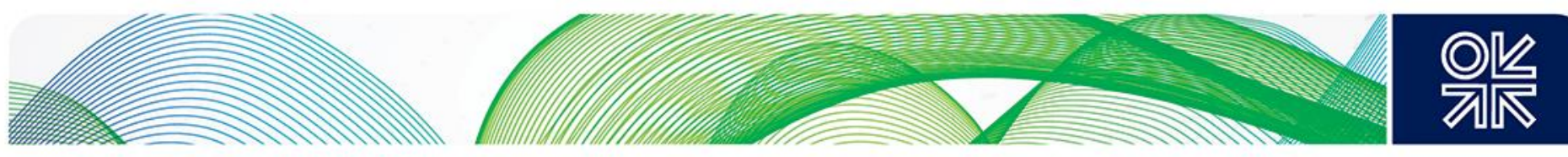

\section{Contents}

Chapter 1. Introduction. .5

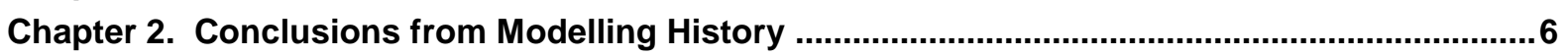

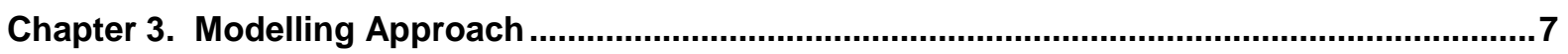

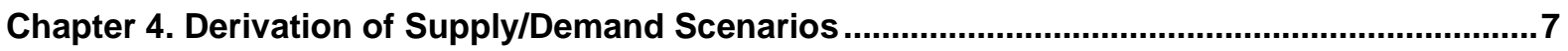

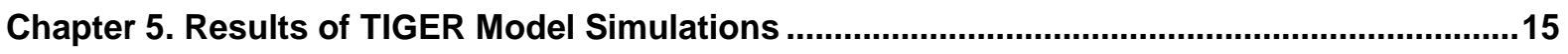

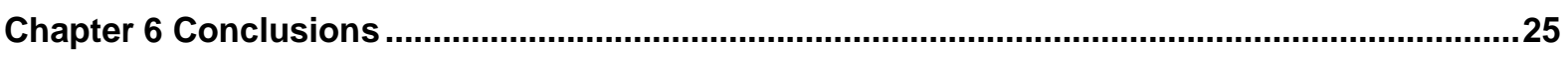

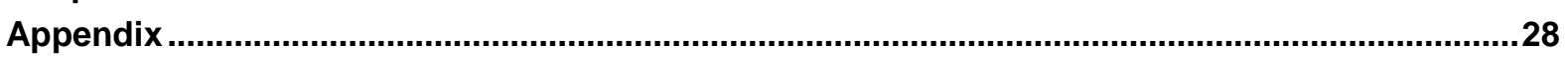

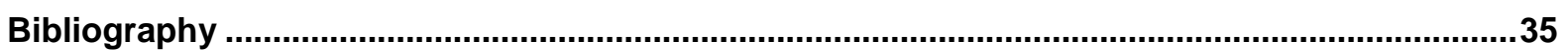

Glossary

\section{Figures}

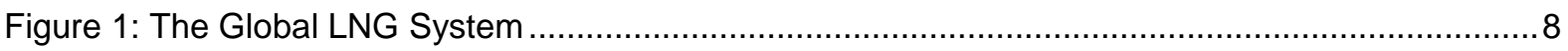

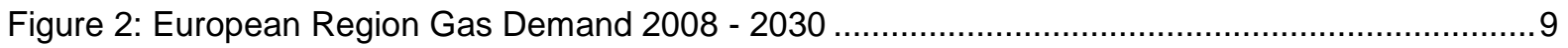

Figure 3: European Region Domestic Production 2008 - 2030 ...................................................... 9

Figure 4: Global LNG Supply 2008 - 2030 from Existing Facilities and Projects under Construction . 10

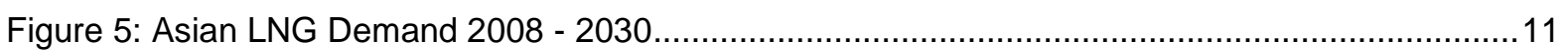

Figure 6: Gazprom's Long Term Take or Pay Contracts with European Customers to 2030 ..............12

Figure 7: Scenario 1. Low Asian Demand with New LNG Projects in the mid 2020s.........................13

Figure 8: Scenario 2. High Asian Demand with New LNG Projects in the mid 2020s .......................... 14

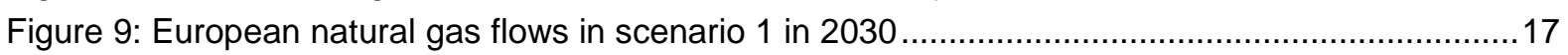

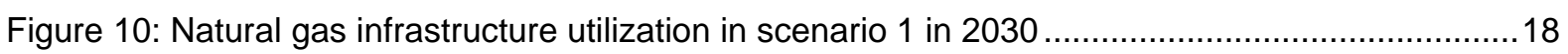

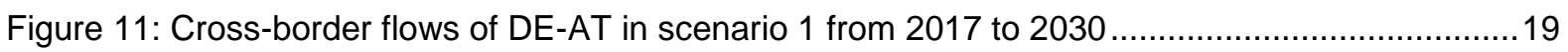

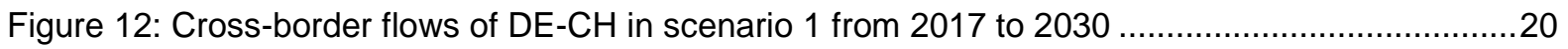

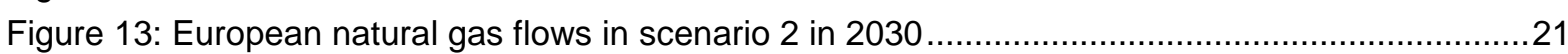

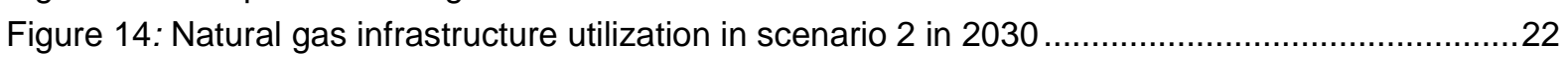

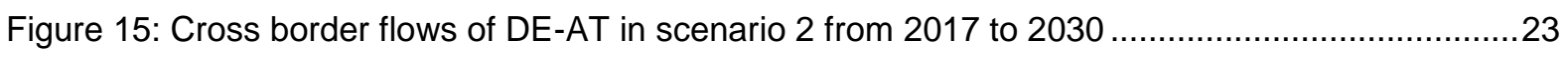

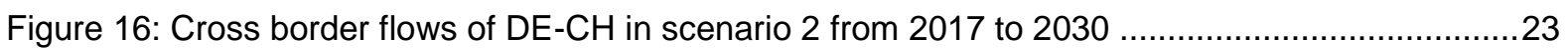

Figure 17: Differences in natural gas flows in scenario 2 in 2030 (if Nord Stream 2 and its connecting

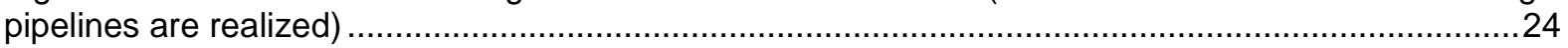

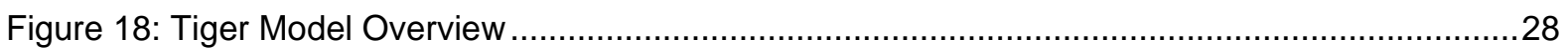

Figure 19: Modelled natural gas infrastructure in the TIGER model (Schematic) ...............................29

Figure 20: Infrastructure utilization in scenario 2 with Nord Stream 2 in 2030 ...................................30

\section{Tables}

Table 1: Scenario 1 Assumed Infrastructure Projects Completed .......................................................16

Table 2: Scenario 2 Assumed Infrastructure Projects Completed ......................................................16 

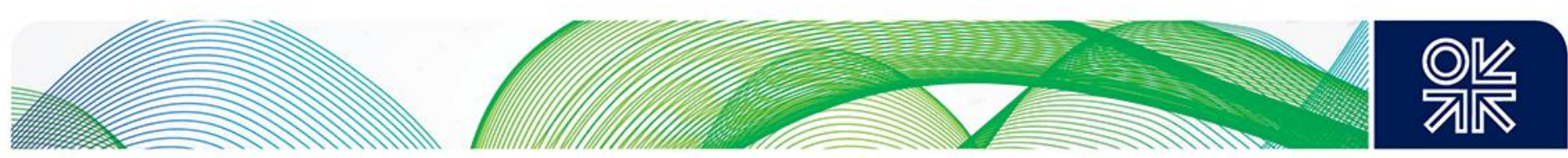

\section{Chapter 1. Introduction}

European gas demand was on a general downward trend between 2010-2015 due to factors which included: the impact of the 2008 financial crisis on European economic activity (reflected in energy demand), the 'squeeze' on gas consumption in the power sector by politically (and financially) supported renewables, and 'cheap' coal in the absence of an effective $\mathrm{CO}_{2}$ pricing system. Other factors included the apparent long-term trend of a reduction in energy intensive industrial activity, the reduction in residential space heating consumption due to improved energy efficiency, and possibly household financial constraints. Initial data for 2016 however, shows an increase in gas demand of some 4 per cent over 2015, in part due to higher use of gas in power generation as the UK minimum carbon price floor took effect, and in the second half of 2016 with the rise in international coal prices.

Given the extensive nature of Europe's existing gas pipeline network, it is therefore surprising that bottlenecks - whether of a temporary or semi-permanent/recurring nature - have been an issue since 2010. In general, these can be explained by the shifting patterns of imported supply of pipeline gas and LNG at European border points, and the consequent challenges of transporting these supplies onwards to consumption centres through systems designed for earlier, different import flow configurations.

Earlier papers by Beatrice Petrovich ${ }^{1}$ and the first paper produced by OIES and EWI-Cologne ${ }^{2}$ identified bottlenecks between Northern and Southern France, between Italy and Northern Europe, and between Germany and Austria. Of these, two appeared to be physical bottlenecks and the third contractual. Not specifically addressed in these studies but of note is the limitation on transport capacity between the Spanish gas market and that of France and the wider European market. The first OIES - EWI Cologne paper took the evidence of bottlenecks from Petrovich's papers (identified by low correlation or 'de-linkage' between the traded gas prices at hubs in the respective regions) and, using historical demand and supply data $^{3}$, 'remodelled history' using the TIGER model, to successfully confirm that periods of de-linkage between the hubs corresponded to physical congestion in pipelines linking these hubs.

The obvious follow-on research question is, given the continued decline in domestic production, how might the situation change in the future given i) uncertainties in future European gas demand trends and differences in the mix of LNG and pipeline imports (principally from Russia), and ii) new infrastructure at various stages of planning/commitment, in particular new LNG import terminals and/or interconnectors, aiming at diversifying supply away from Russian gas, principally in the Baltic states and in South East Europe.

This is far from an academic exercise. Petrovich (2015) ${ }^{4}$ estimated that bottlenecks in Europe during 2014 represented a cost to end consumers in Italy of some $€ 300$ million as a consequence of hub prices being higher than those prevailing on the hubs of North West Europe. Moreover, the additional gas procurement cost in 2014 caused by physical congestion between Germany and Austria can be estimated at about $€ 60$ million; additionally, de-linkage of prices in the South of France compared to those in the adjacent PEGN translated into $€ 240$ million in the same year (Petrovich 2015).

This paper also addresses an additional question: 'Under different future supply/demand and import flow scenarios, do the bottlenecks observed in the 2012-2015 period endure, get worse or are they alleviated'? It is intended that this paper will provide insight and relevance to regulators and system operators in their deliberations on system expansion decisions.

\footnotetext{
Petrovich $(2013,2014,2015)$.

2 OIES \& EWI (2016).

${ }^{3}$ Including domestic production, pipeline gas imports and LNG imports.

${ }^{4}$ Petrovich (2015).
} 

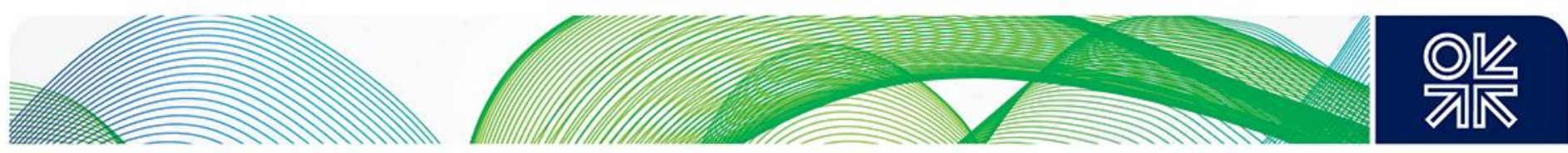

However, this analysis focuses purely on the occurrence of bottlenecks, and it does not discuss welfare implications. In fact, as already pointed out by Lochner (2012), the removal of a bottleneck is not necessarily efficient from a system point of view, since the cost of additional investment to remove the bottleneck could be higher than the costs of a price de-linkage caused by the bottleneck.

Chapter 2 briefly reprises the conclusions from the first OIES - EWI paper, which focussed on the historical position. Chapter 3 describes the overall approach and methodology of this paper including a summary description of the TIGER model and the process for transforming input assumptions into 'digestible data'.

Chapter 4 summarises the derivation of supply/demand scenarios within which the European import trajectory of pipeline gas and LNG are defined, and Chapter 5 discusses the results and implications of such modelling. Chapter 6 presents the conclusions.

A more detailed description of the TIGER model is contained in the Appendix.

\section{Chapter 2. Conclusions from Modelling History}

Barriers remain to the free trade of gas between some of the main European gas hubs, as shown by recurrent price misalignment between relatively large and mature gas consuming zones: between Northern and Southern France, between Germany and Austria, and between North West European hubs and the Italian market.

The analysis in the previous OIES-EWI paper ${ }^{5}$ explored the driving forces behind such disconnections, and in particular whether these would be present in a fully competitive setting where all gas suppliers to Europe are price takers and the use of cross-border transmission capacity is optimized (specifically where the existing infrastructure is fully exploited to carry out arbitrage activities and transport costs are minimized). The analysis adopted as its benchmark the least cost flow pattern within the European grid determined by the TIGER model created by EWI for a selected calendar year (2014) once key import/export flows, domestic production and demand had been fixed at historically observed levels.

By 're-running history', we verified the physical nature of the bottleneck within the French grid and the sub-optimal utilization of transmission capacity on the NCG-Switzerland-Italy route, which in turn contributed to heavy gas flows in the Germany to Austria direction that did not conform to 'pure economic logic' and led to the recurring disconnection of the Austrian market. Moreover, the presence of long term shipping contracts on the Transitgas route, difficulties in making transmission capacity available to other participants when not nominated by the original owner, and insufficiently flexible capacity allocation procedures appeared to be obstacles to shipping gas on a spot basis from Germany to Italy, via Switzerland. However, the confidentiality of shipping contract terms and bookings on this route did not allow to us to establish robust evidence for this argument.

The somewhat limited possibility of fully utilizing the Transitgas pipeline system creates a case for shipping gas from the liquid gas markets in North West Europe to Italy through Austria. This alternative route to the PSV puts pressure on the Oberkappel IP and increases the need to ship gas eastward from Germany via Austria. This situation was exacerbated when the cessation of Russian supplies to Ukraine in the second half of 2014 led to substantial reverse (eastward) flows. The request to move significant volumes from NCG to the Austrian VTP led to the saturation of the transmission capacity at Oberkappel and hence to physical congestion between Germany and Austria.

Turning to the French case study, the comparison between reality and simulation for gas flow between the two main French market zones corroborates the argument that if more transmission capacity was made available in the North to South direction, this would most likely favour the creation

${ }^{5}$ OIES \& EWI (2016) 

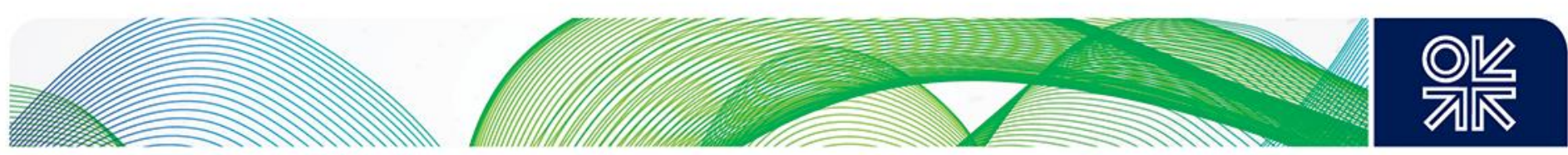

of a single price for natural gas within France in times of LNG scarcity in the South of France and high exports to Spain.

This work complements and corroborates the findings of the price delinkage analysis carried out by OIES to identify the remaining barriers to the free trade of natural gas in Europe. OIES research proved that even in a mature and well-integrated European gas market, it may be that for some periods, as a consequence of changes in gas flow patterns across Europe, a hub may split from the others and display a price dynamic which is completely different from the others, possibly resulting in higher costs.

Anticipating future bottlenecks would help to assess whether there is a case for developing suitable frameworks/incentives aimed at mitigating the potential future factors which would act as barriers to price integration in the European gas market.

\section{Chapter 3. Modelling Approach}

The analysis for this paper was undertaken using the European supply-demand transmission model TIGER. The TIGER model was developed by EWI at the University of Cologne; it works using as inputs: demand, production capacities of major gas suppliers, European domestic production, information on long term contracts, and transmission tariffs data, and gives as an output a pattern of physical gas flows within Europe. TIGER is a cost-minimizing model: the whole system is optimized with regard to the cost of gas supply, subject to several infrastructure constraints, for example capacity limits of pipelines or injection/withdrawal storage curves. Consequently, TIGER-simulated flows are the optimal ones, meaning that such flows imply every arbitrage opportunity has been exploited to the extent that available infrastructure allows. For a technical model description, please refer to Lochner (2012).

OIES has published many papers based on future European region supply/demand scenarios in the context of a global LNG balance ${ }^{6}$. The solution for Europe from this global balance model includes monthly values for production, consumption, pipeline imports, LNG imports and exports, and storage inventories. These can be converted into daily values for input into the TIGER model.

With this input data and assumptions on infrastructure capacities and tariffs, the TIGER model simulates the least cost pattern of flows within the European grid (essentially the flow pattern within Europe that minimizes transport costs, subject to capacity constraints).

\section{Chapter 4. Derivation of Supply/Demand Scenarios}

Future supply/demand scenarios for Europe are defined within the balance of a 'global system' connected by LNG, as shown in Figure 1. In this system, global LNG supply is imported by the five established Asian LNG importers (Japan, South Korea, Taiwan, China, and India). The new and niche markets - in Asia, the Middle East and in South and Central America - are also taken into account. What is left over is available for the Atlantic basin markets of North America and Europe ${ }^{7}$. Since the onset of the US shale gas revolution however, North America has had a minimal requirement for LNG imports and indeed, the first export cargo of Lower 48-sourced LNG left the US Gulf Coast in February 2016.

\footnotetext{
${ }^{6}$ See Rogers (2015) and earlier work by the same author on the OIES website.

${ }^{7}$ This is a slightly simplistic representation as Europe has some LNG on long term contract, but in overall terms the model is valid and such contractual commitments can be taken in account.
} 

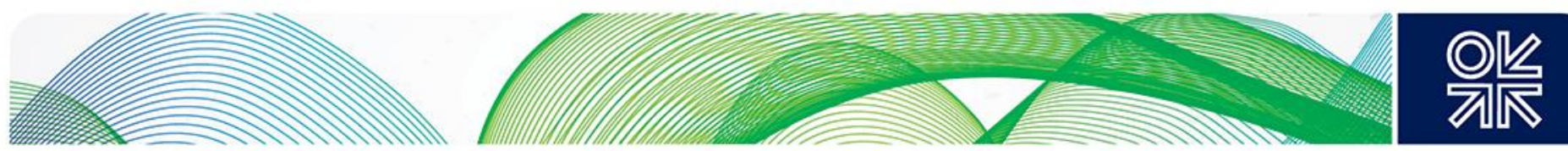

Figure 1: The Global LNG System

\section{Global LNG System}

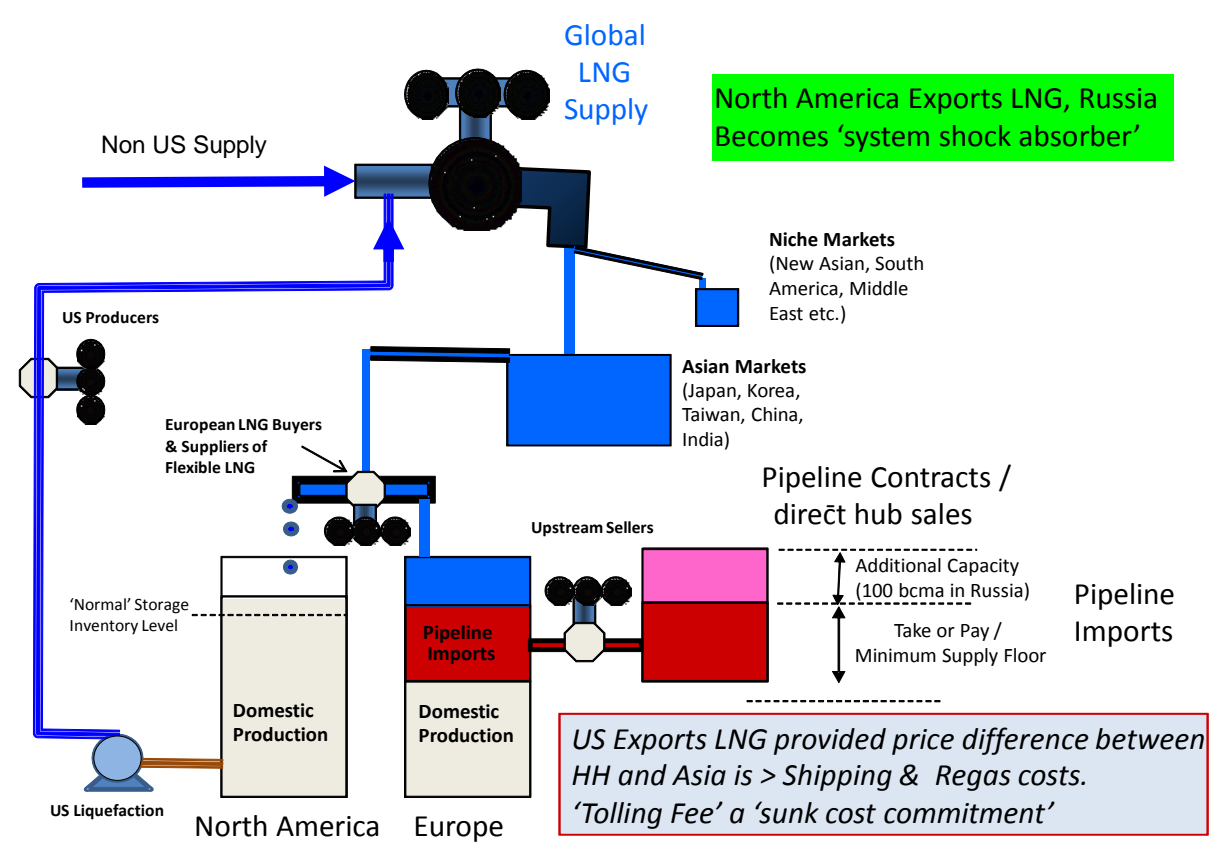

Source: Authors

The European region has other sources of gas supply. Its domestic production is mainly from Norway, the Netherlands and the UK. Of these, the UK and Netherland's production is in decline and the level of Norwegian production beyond 2020 is open to question. Pipeline gas from Algeria, Libya, Azerbaijan, Iran (to Turkey) and, most notably, Russia has historically contributed some 40 per cent of Europe's gas supply.

The four key parameters which will determine the scale and nature of European import flows from the present through the 2020s are: future European gas demand, the domestic production trajectory, LNG available for Europe (from the global balance), and Russian pipeline supplies making up the balance. These are described individually below.

\section{European Gas Demand}

Figure 2 shows a historical and a future view of European gas demand based on Anouk Honoré's Base Case ${ }^{8}$. Growth in gas demand is based on the assumed retiral of coal and nuclear plants and a slowing in the pace of renewable investment in the 2020s.

\footnotetext{
${ }^{8}$ Anouk Honoré (OIES) 2017, Forthcoming
} 

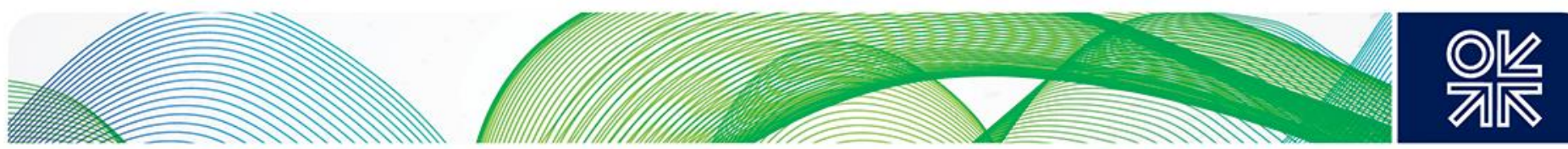

Figure 2: European Region Gas Demand 2008 - 2030

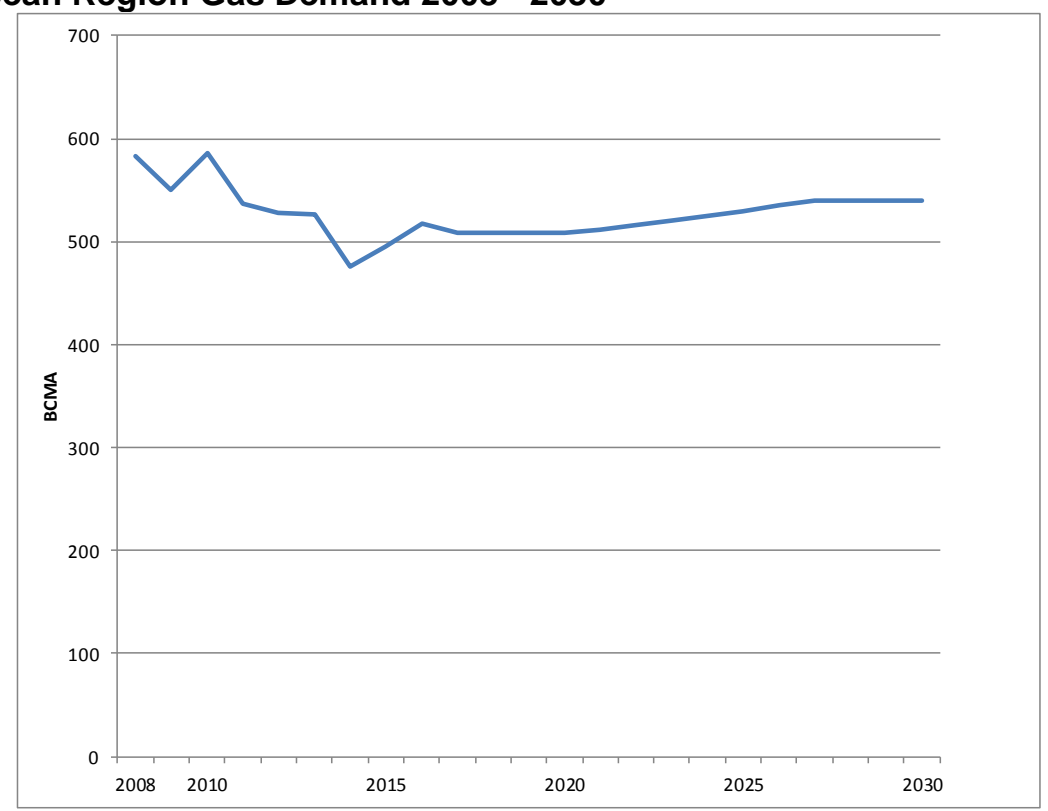

Source: Based on Honoré, OIES

\section{Domestic Production Trajectory}

Even on this trajectory, which is lower than the previous consensus European gas demand outlook, Europe will need to increase its imports of pipeline gas and LNG as domestic production declines. Figure 3 shows the outlook for European domestic production to 2030.

Figure 3: European Region Domestic Production 2008 - 2030

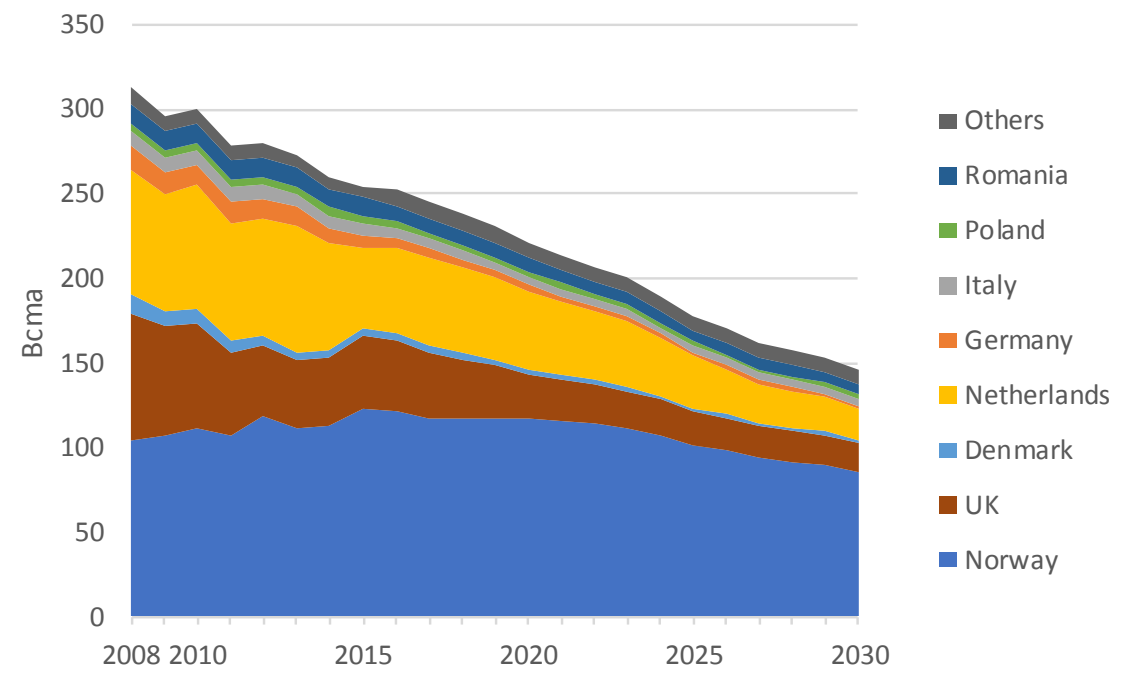

Sources: IEA, National Grid, Dutch Ministry of Foreign Affairs, Energi Styrelsen, Norwegian Ministry of Petroleum and Energy, Authors' Analysis

Total domestic production in Figure 3 declines from $254 \mathrm{bcma}$ in 2015 to $140 \mathrm{bcma}$ in 2030. Of the major producers, Norway is expected to maintain its plateau until the early-mid 2020s and then commence a gradual decline as new discoveries become smaller and further away from existing 

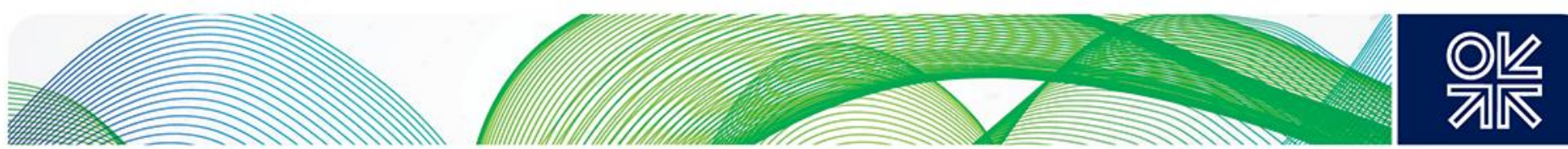

infrastructure, while the Netherlands is expected to maintain restrictions on Groningen field production (to ameliorate earth tremors) and only modest new production is expected. Meanwhile the UK is expected to continue its long term production decline although a notional $5 \mathrm{bcma}$ of shale gas/prospective upside has been included in the 2020s ${ }^{9}$. There appears little potential for production upside elsewhere in the region.

\section{LNG Supply}

The surge in Asian LNG demand from 2009 to 2012, coinciding with the hike in the oil price (and hence the price of LNG under long term oil indexed contracts), provided the incentive for a proliferation of new LNG supply. By 2020, new LNG supply from projects under construction, chiefly in Australia, the USA and Russia, will take global LNG supply to above 500 bcma, compared with the 2015 level of 330 bcma.

\section{Figure 4: Global LNG Supply 2008 - 2030 from Existing Facilities and Projects under Construction}

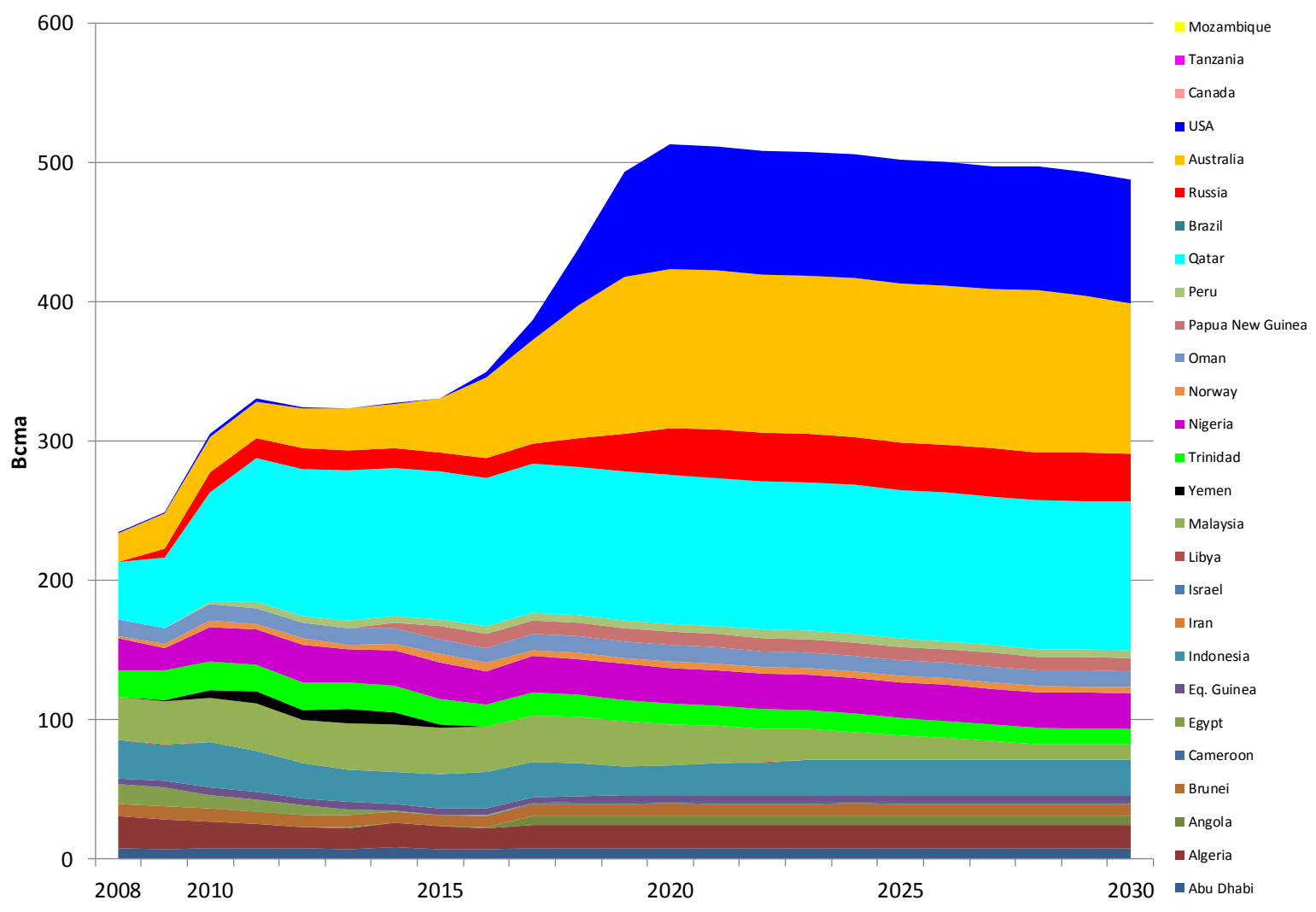

Source: Authors' Assumptions

Although the pace of new LNG project FID's has slowed noticeably during 2015 and 2016, Tangguh Train 3, Wood Fibre (Canada), and potentially Coral (Mozambique) represent examples of countercyclical investment. Pre-FID projects in various stages of definition, notably in the US, East Africa, Australia, Russia, and Canada, represent significant additional LNG supply potential awaiting signs of more positive fundamentals for LNG demand, given that the time from FID to production is typically five years for these projects.

A critical factor driving the timing of the need for new LNG supply and how much of this is available for Europe is the evolution of Asian LNG requirements. This is shown in Figure 5.

\footnotetext{
${ }^{9}$ It is questionable whether this will be realised however.
} 

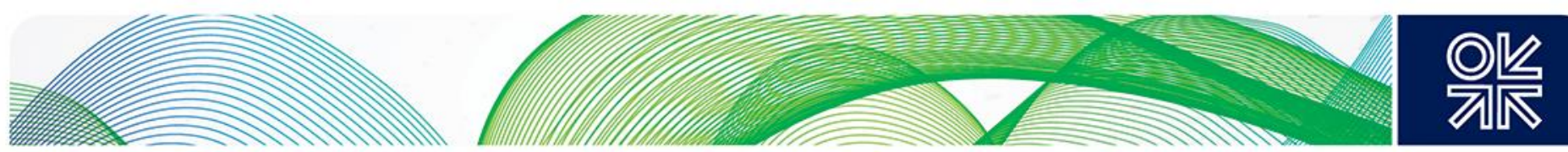

Figure 5: Asian LNG Demand 2008 - 2030

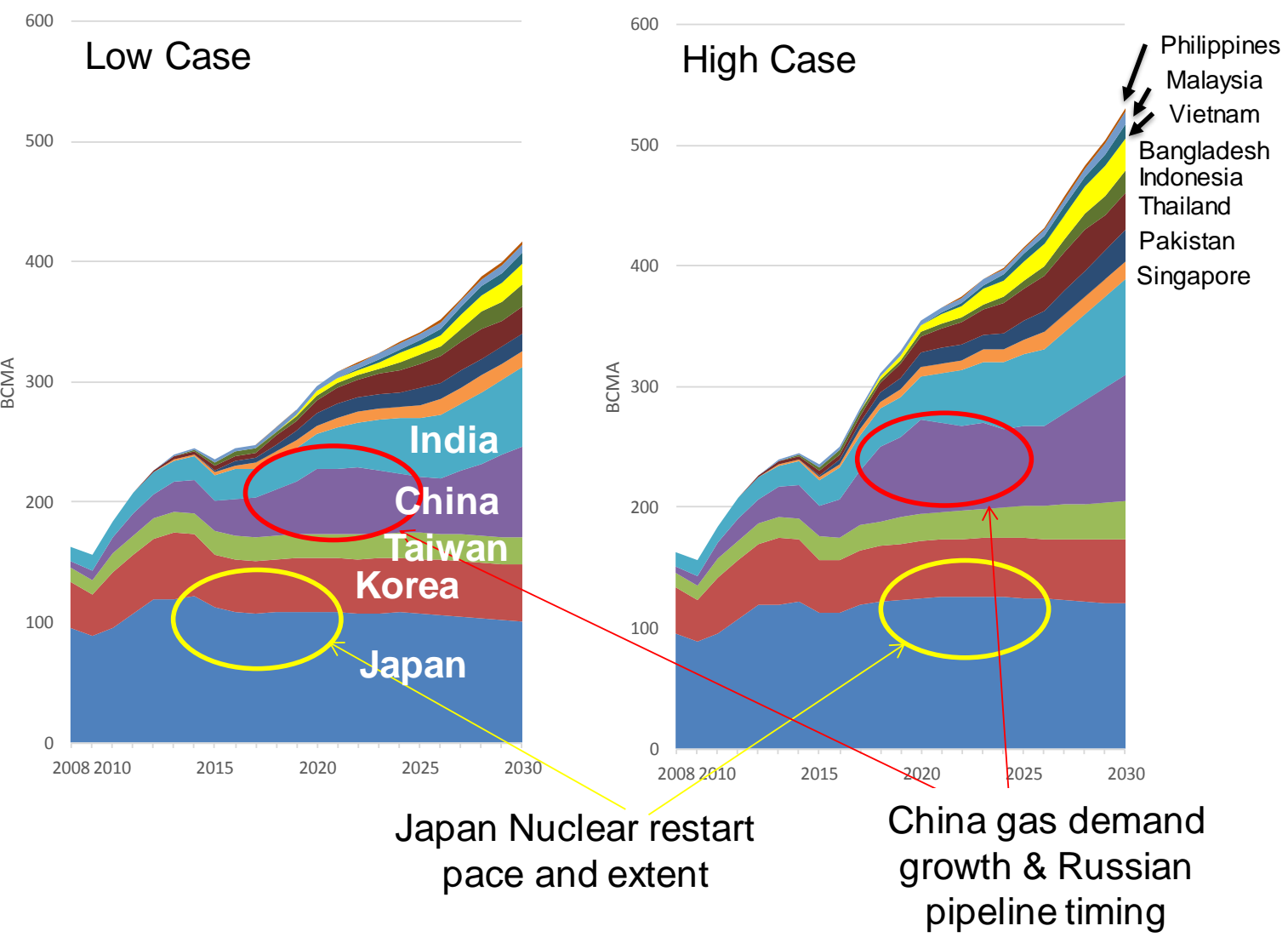

Source: Based on Rogers (2016)

Uncertainties in Asian LNG demand through to 2025 chiefly relate to the pace and extent of Japan's nuclear re-start programme and China's gas demand growth, plus the balance of pipeline versus LNG. In the longer term to 2030, the evolution of gas in India's energy mix and the development of LNG penetration in Pakistan, Thailand, Vietnam, Bangladesh, and others is, in aggregate, highly important.

\section{Russian Pipeline Gas Imports}

Russia is the single largest supplier of natural gas to the European region, via a pipeline network entering NW, Central and SE Europe. Figure 6 shows recent annual import volumes compared with the legacy suite of long term contracts which extend to 2030 and beyond. 

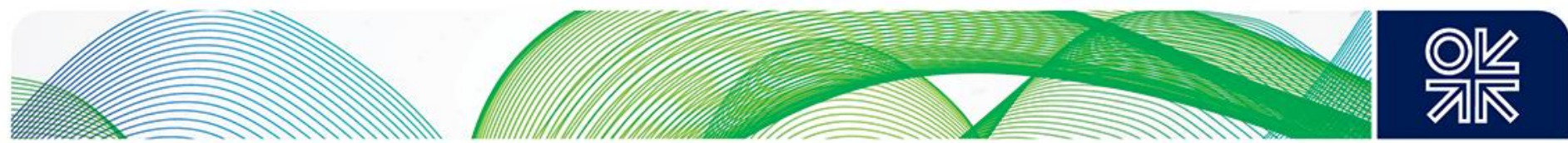

Figure 6: Gazprom's Long Term Take or Pay Contracts with European Customers to 2030

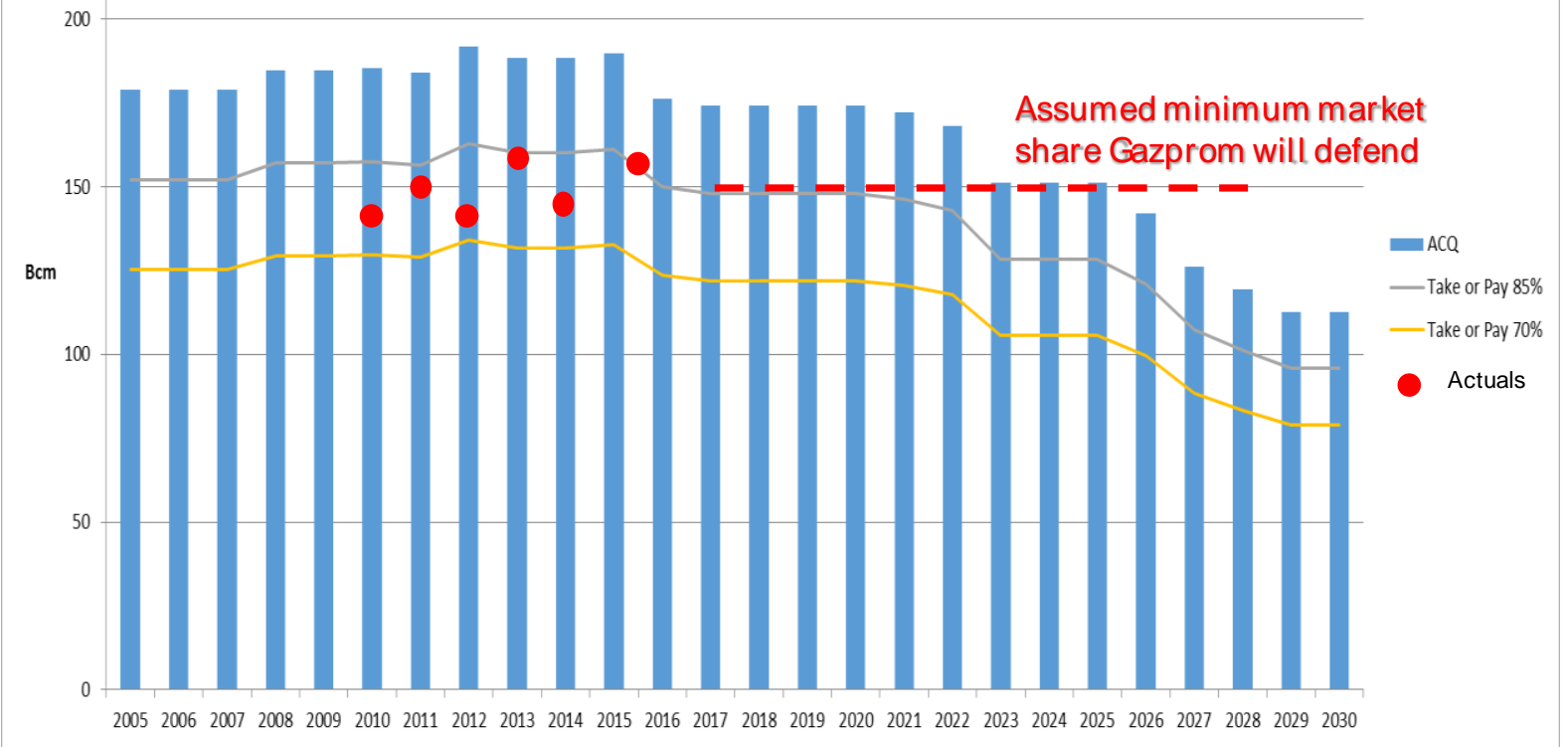

Source: ERI RAS in Henderson and Pirani (2014)

As LNG supply builds from 2016 to 2020 , any volume surplus to Asian and other market requirements will enter the European market via its 217 bcma of LNG regas import capacity. Especially in the 'Low Asian Demand Case', this will directly compete with Russian pipeline gas exports to Europe. It is possible that, given verbal statements at conferences ${ }^{10}$, Gazprom/Russia will defend a European region market share of $150 \mathrm{bcma}$ for the duration of an LNG supply glut. This would depress European hub prices, ultimately to the point where the slender spread with Henry Hub constrains the volume of US LNG exports, thus allowing the market to 'clear'. Beyond the glut and ahead of a new wave of LNG supply, Russian exports to Europe would increase, giving Russia a large degree of market/pricing power. Due to the development of the Bovanenko field and through the activities of Rosneft, Lukoil, and Novatek in developing gas supply for the Russian domestic market (and taking share from Gazprom), Russia has a productive gas production 'bubble' of some 100 bcma above demand (domestic and export). Pipeline imports from Algeria, Libya, Azerbaijan, and Iran are also accounted for in balances but play a minor role compared to those of Russia and have limited, if any, upside potential.

New LNG supply (beyond existing projects under construction) will be needed from the mid-2020s. While there is no shortage of new LNG supply potential, the five year lead-times involved create the possibility of a recurrence of the present 'commodity cycle' LNG supply phenomenon. This makes it virtually impossible to forecast 2030 levels of global LNG supply and, combined with the uncertainties over future Asian LNG demand growth, creates a wide range of possibilities for the relative share of LNG and Russian gas imports for Europe in this timescale.

\section{Resulting Scenarios for TIGER Modelling}

Given the uncertainties pertaining to the scale and nature of the European supply mix to 2030 described above, it is important to reiterate the primary objectives of the modelling analysis which are:

- To observe whether the identified historic bottlenecks a) between Northern and Southern France and b) between Germany and Italy are resolved or made worse as Europe's supply mix changes and;

${ }^{10}$ For example by Elena Burmistrova at the FLAME Conference, Amsterdam, May 2016 

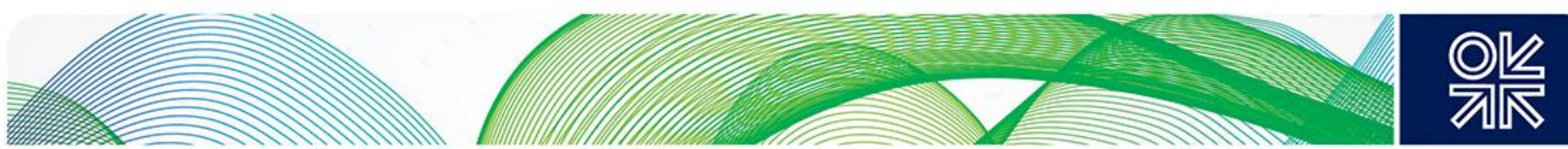

- To identify additional bottlenecks which might develop through the 2020s.

Rather than dive into the detail of scenarios which are subject to a high level of uncertainty and frequent revision, the TIGER modelling analysis will focus on the 2030 position for two illustrative scenarios:

Scenario 1: Low Asian Demand with New LNG Projects in mid-2020's. In this scenario higher LNG availability depresses the level of Russian pipeline imports into Europe, as shown in Figure 7.

Figure 7: Scenario 1. Low Asian Demand with New LNG Projects in the mid 2020s

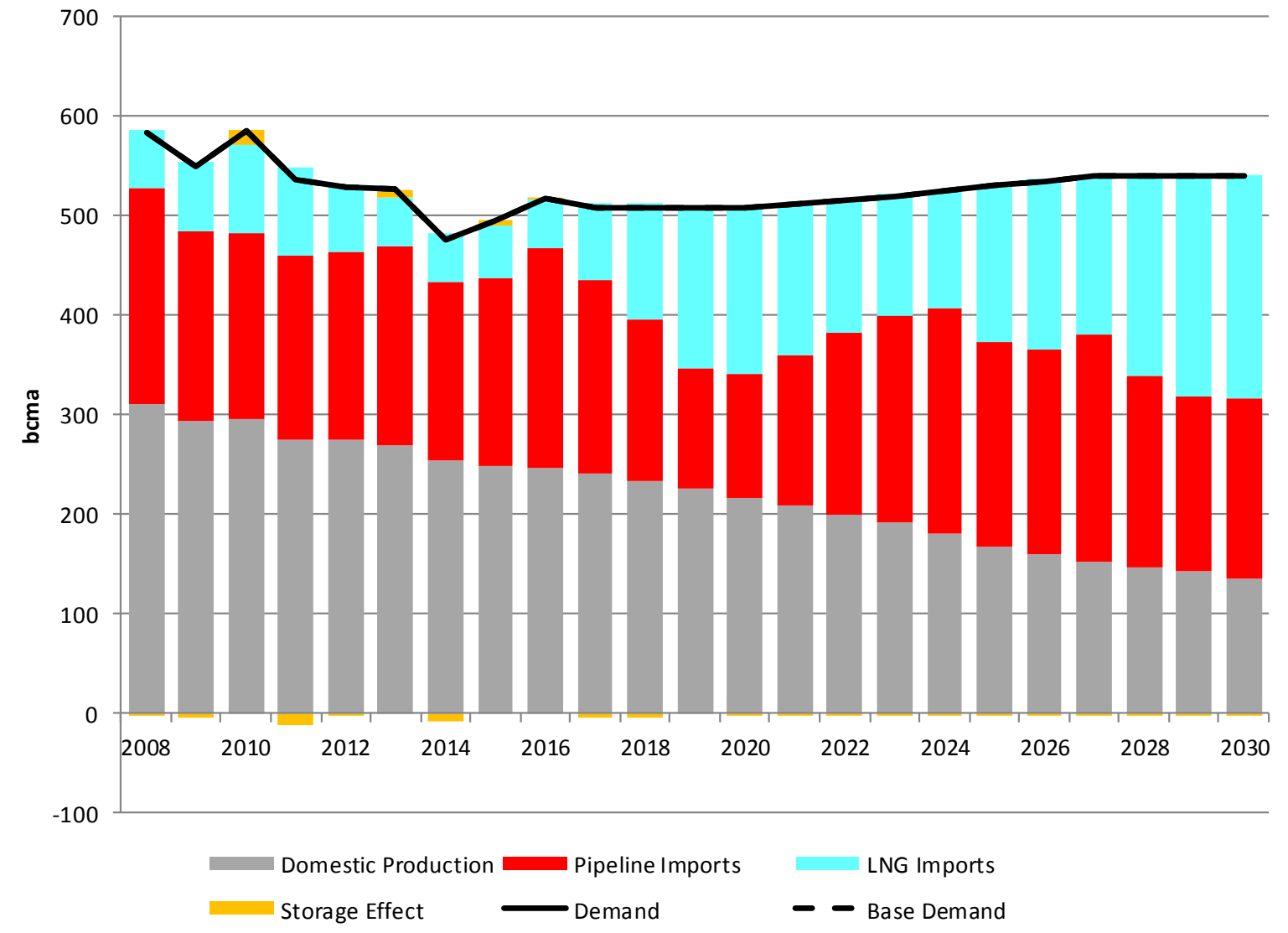

Source: Authors' Assumptions and Analysis

With lower Asian LNG demand growth, Figure 7 shows higher levels of European LNG imports through to 2030. Around 2019 and 2020 these levels might be contested by Russian pipeline gas and therefore seek other market clearing mechanisms ${ }^{11}$. By 2030, Europe imports some 225 bcma of LNG and 180 bcma of pipeline imports.

\footnotetext{
${ }^{11}$ These include i) coal to gas switching in the European power sector (namely higher European demand), ii) additional Asian industrial demand, and iii) constrained exports from the most expensive US offtakers.
} 

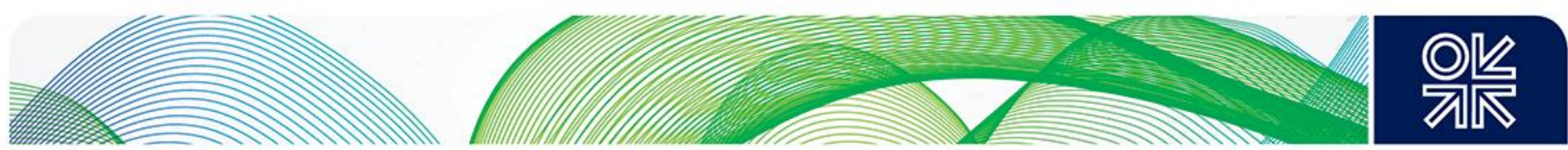

The key parameters for 2020, 2025 and 2030 (with values for 2015 and 2016 for comparison) are:

\begin{tabular}{lrrrrr} 
& \multicolumn{5}{c}{ BCMA } \\
& $\mathbf{2 0 1 5}$ & $\mathbf{2 0 1 6}$ & $\mathbf{2 0 2 0}$ & $\mathbf{2 0 2 5}$ & $\mathbf{2 0 3 0}$ \\
Demand & 495.9 & 517.4 & 508.0 & 530.0 & 540.0 \\
Domestic Production & 254.3 & 252.4 & 221.4 & 172.8 & 140.9 \\
LNG Exports & 6.1 & 6.2 & 4.7 & 4.6 & 4.6 \\
LNG imports & 51.5 & 49.7 & 169.1 & 159.0 & 224.7 \\
Russian Pipeline Imports & 159.8 & 171.7 & 92.0 & 171.5 & 149.8 \\
Other Pipeline Imports & 30.0 & 49.2 & 31.7 & 32.9 & 30.8 \\
Storage Inventory Change & 6.4 & 0.6 & -1.5 & -1.5 & -1.5
\end{tabular}

Scenario 2: High Asian Demand with New LNG Projects in the mid-2020s. In this scenario the European import requirement grows through the 2020s as domestic production declines and demand grows. Figure 8 illustrates the trend.

Figure 8: Scenario 2. High Asian Demand with New LNG Projects in the mid 2020s

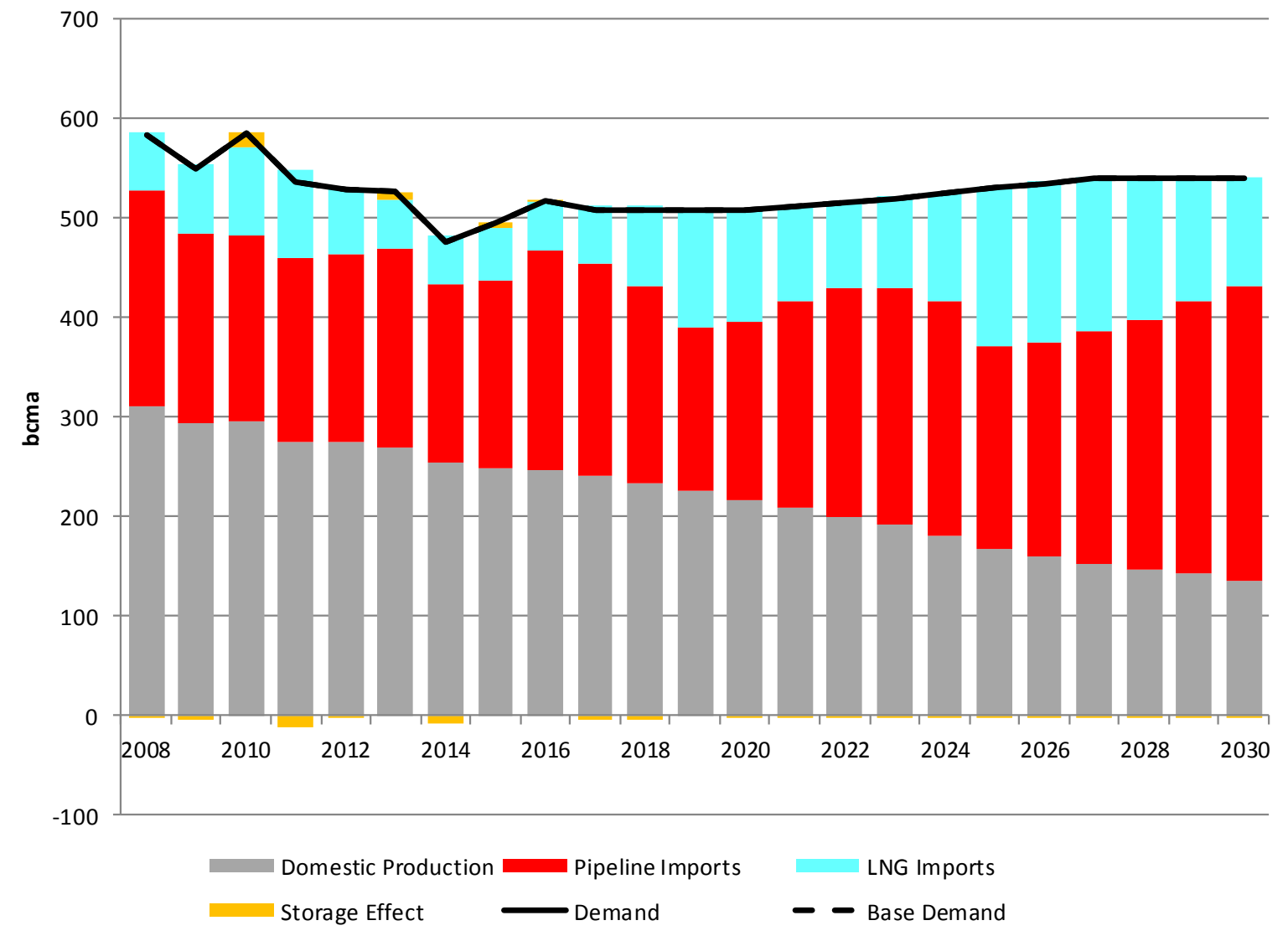

Source: Authors' Assumptions and Analysis

Figure 8 shows growth in European LNG imports to 2019 and 2020, followed by a reduction (as Asian demand growth pulls LNG away from Europe), pending the arrival of supply from new LNG projects from 2024 onwards. Continued Asian LNG demand growth however continues to diminish European LNG imports from 2027 to 2030. 

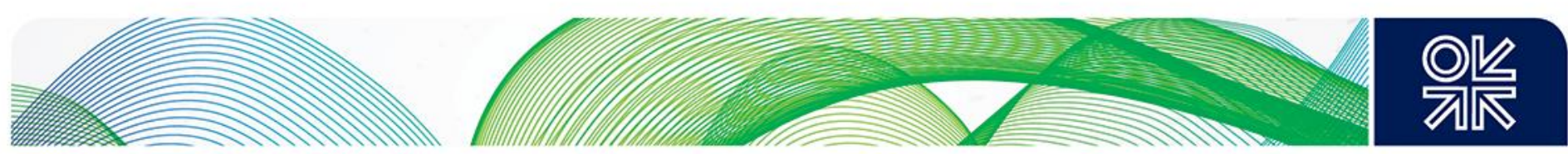

The key parameters for 2020, 2025 and 2030, (with values for 2015 and 2016 for comparison) are:

\begin{tabular}{lrrrrr} 
& \multicolumn{5}{c}{ BCMA } \\
& $\mathbf{2 0 1 5}$ & $\mathbf{2 0 1 6}$ & $\mathbf{2 0 2 0}$ & $\mathbf{2 0 2 5}$ & $\mathbf{2 0 3 0}$ \\
Demand & 495.9 & 517.4 & 508.0 & 530.0 & 540.0 \\
Domestic Production & 254.3 & 252.4 & 221.4 & 172.8 & 140.9 \\
LNG Exports & 6.1 & 6.2 & 4.7 & 4.6 & 4.6 \\
LNG imports & 51.5 & 49.7 & 112.9 & 160.3 & 109.7 \\
Russian Pipeline Imports & 159.8 & 171.7 & 140.2 & 170.3 & 254.7 \\
Other Pipeline Imports & 30.0 & 49.2 & 39.7 & 32.7 & 40.8 \\
Storage Inventory Change & 6.4 & 0.6 & -1.5 & -1.5 & -1.5
\end{tabular}

\section{Chapter 5. Results of TIGER Model Simulations}

The two scenarios derived in Chapter 4 are simulated with the European gas market model TIGER, which has been developed and is regularly maintained by ewi ER\&S. The simulation results are described below, first from the perspective of European (regional) cross-border import capacity and secondly with a focus on bottlenecks within the European transmission system.

\section{Infrastructure Assumptions}

Beside the above-mentioned assumptions about the future development of supply and demand, additional infrastructure assumptions are necessary. In general, TIGER includes data on existing European gas infrastructure. Cross-border pipeline capacities, LNG import capacities as well as natural gas storage capacities have been collected in a detailed database that is updated regularly and supplemented with public data from Gas Infrastructure Europe ${ }^{12}$. Furthermore, future infrastructure projects are based on ENTSOG ${ }^{13}$. All projects with final investment decision (FID) are included ${ }^{14}$ as attached in the appendix. However, since the above-mentioned supply scenarios represent two contrasting situations with either high LNG imports (Scenario 1) or high Russian gas imports (Scenario 2), some additional infrastructure projects are necessary to realize the assumed country-wide supply and demand balances for each scenario. Therefore, the gas infrastructure projects as described in Table 1 and Table 2 are additionally included in the model. This additional infrastructure consists of planned projects that have a non-FID status. They are necessary to ensure that no shortfall occurs. Due to the assumed decrease in Algerian pipeline imports to Europe, a realization of Italian LNG projects is assumed, although the likelihood that they are actually commissioned is considered rather low ${ }^{15}$.

\footnotetext{
12 GIE (2016), GLE (2016), GSE (2016)

${ }^{13}$ ENTSOG - TYNDP (2017)

${ }^{14}$ With the exception of expansion in the French transmission capacity. In fact, notwithstanding that TYNDP 2017 includes a FID project for $999 \mathrm{GWh} / \mathrm{y}$, we assume that the PEGN-TSR capacity remains at today's level $(440 \mathrm{GWh} / \mathrm{d})$ due to lack of further public information regarding the planned expansion (at least to the best of our knowledge, which is based on publicly available information). As explained below, we have assumed that the French Nord-Sud link is expanded or does not affect the outlook for the historically observed French bottleneck.

${ }^{15}$ The investment in new Italian regasification capacity is considered unlikely but is motivated by the bearish view on Algerian supply, which seems likely unless Algeria radically changes its ability to revitalize upstream strategy - rather than 'borrowing' Hassi R'Mel recycle gas. In the scenario in question, where there is ample LNG available and the view on Algeria supply is bearish, if Italy did not expand its regas capacity to attract its 'share' of this, the result would be bottlenecks between Italy and the rest of Europe
} 

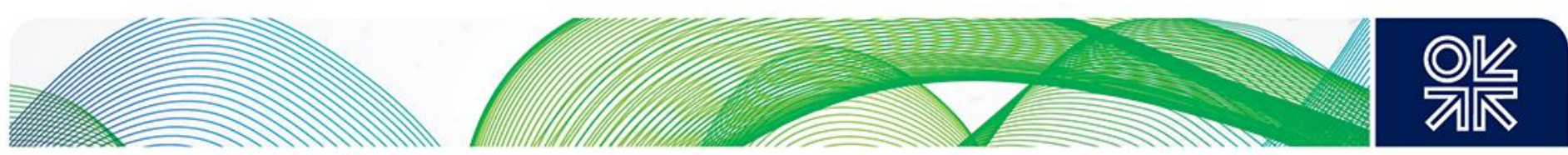

Table 1: Scenario 1 Assumed Infrastructure Projects Completed

\begin{tabular}{|l|l|l|l|}
\hline Project & $\begin{array}{l}\text { Total } \\
\text { Capacity }\end{array}$ & Starting date & Comment \\
\hline OPAL & $\begin{array}{l}32 \mathrm{bcm} / \mathrm{a} \\
(+16 \mathrm{bcm} / \mathrm{a})\end{array}$ & 2020 & $\begin{array}{l}\text { Non-regulated part of OPAL can be } \\
\text { used at its full technical capacity of 32 } \\
\text { bcm/a }\end{array}$ \\
\hline GIPL & $2 \mathrm{bcm} / \mathrm{a}$ & 2020 & $\begin{array}{l}\text { Interconnection Poland-Lithuania (bi- } \\
\text { directional) }\end{array}$ \\
\hline Turkish Stream & $16 \mathrm{bcm} / \mathrm{a}$ & 2018 & $\begin{array}{l}\text { Only one string is built (for Turkish } \\
\text { market only) }\end{array}$ \\
\hline Midcat & $7 \mathrm{bcm} / \mathrm{a}$ & 2021 & $\begin{array}{l}\text { Interconnection Spain to France (bi- } \\
\text { directional) }\end{array}$ \\
\hline Krk LNG (Croatia) & $6 \mathrm{bcm} / \mathrm{a}$ & $2019 / 2021 / 2023$ & Three stages \\
\hline $\begin{array}{l}\text { Porto Empedocle LNG } \\
\text { (Italy) }\end{array}$ & $8 \mathrm{bcm} / \mathrm{a}$ & 2020 & \\
\hline Gioia Tauro LNG (Italy) & $12 \mathrm{bcm} / \mathrm{a}$ & 2019 & \\
\hline Ancona LNG (Italy) & $4 \mathrm{bcm} / \mathrm{a}$ & 2018 & \\
\hline
\end{tabular}

Source: Authors' Assumptions

Table 2: Scenario 2 Assumed Infrastructure Projects Completed

\begin{tabular}{|l|l|l|l|}
\hline Project & $\begin{array}{l}\text { Total } \\
\text { Capacity }\end{array}$ & Starting date & Comment \\
\hline OPAL & $\begin{array}{l}32 \mathrm{bcm} / \mathrm{a} \\
(+16 \mathrm{bcm} / \mathrm{a})\end{array}$ & 2020 & $\begin{array}{l}\text { Non-regulated part of OPAL can be } \\
\text { used at its full technical capacity of } 32 \\
\text { bcm/a }\end{array}$ \\
\hline GIPL & $2 \mathrm{bcm} / \mathrm{a}$ & 2020 & $\begin{array}{l}\text { Interconnection Poland-Lithuania (bi- } \\
\text { directional) }\end{array}$ \\
\hline Turkish Stream & $32 \mathrm{bcm} / \mathrm{a}$ & $2018 / 2020$ & Two strings at 16 bcm each \\
\hline Trans-Balkan-Reverse & $16 \mathrm{bcm} / \mathrm{a}$ & 2020 & Connection for Turkish Stream \\
\hline Midcat & $7 \mathrm{bcm} / \mathrm{a}$ & 2021 & $\begin{array}{l}\text { Interconnection Spain to France (bi- } \\
\text { directional) }\end{array}$ \\
\hline
\end{tabular}

Source: Authors' Assumptions

Assumptions about transport costs are based on the entry/exit tariffs of each European market area as reported in the ACER Market monitoring report $2015^{16}$ (ACER 2016). Ukrainian entry/exit tariffs are based on Interfax (2015). All entry/exit fees are assumed to be constant until 2030.

The pipeline project Nord Stream 2 that directly connects Russia and Germany via the Baltic Sea is not part of the initial set of future infrastructure assumptions. Due to current controversial economic ${ }^{17}$, political, and legal discussions, the project and its impact on the European market will be analysed separately in a discrete sensitivity analysis. The infrastructure assumptions of the project are based on the "more capacity" initiative which has been initiated by the three German transmission system operators (TSO): Gascade Gastransport GmbH, Gasunie Deutschland Transport Services GmbH and ONTRAS Gastransport GmbH. ${ }^{18}$

\footnotetext{
${ }^{16}$ ACER (2016).

${ }^{17}$ For a more detailed analysis of the economics of Nord Stream 2 see Hecking et al (2016)

18 https://www.more-capacity.eu/en/contact/
} 

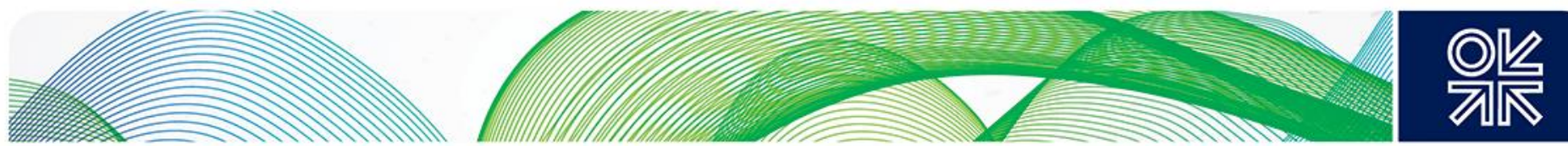

\section{Scenario 1: Low Asian Demand with New LNG Projects in the mid 2020s}

In the first simulated scenario, low Asian demand development and new investments in LNG export capacities are assumed. As already described in Chapter 4, this low Asian demand would lead to an oversupply of LNG and hence a glut in the European market which would partly suppress Russian gas supply. In this scenario, up to $225 \mathrm{bcm}$ of LNG would enter the European market in 2030. Figure shows where these LNG volumes would enter the market and the resulting European gas flows. It depicts the main annual cross-border natural gas flows and the respective interconnection capacities (in brackets) in billion cubic meters $(\mathrm{bcm})$ for the year 2030. Furthermore, the grey stars represent the individual European LNG import terminals, their import flows and their respective capacities (in brackets).

\section{Figure 9: European natural gas flows in scenario 1 in 2030}

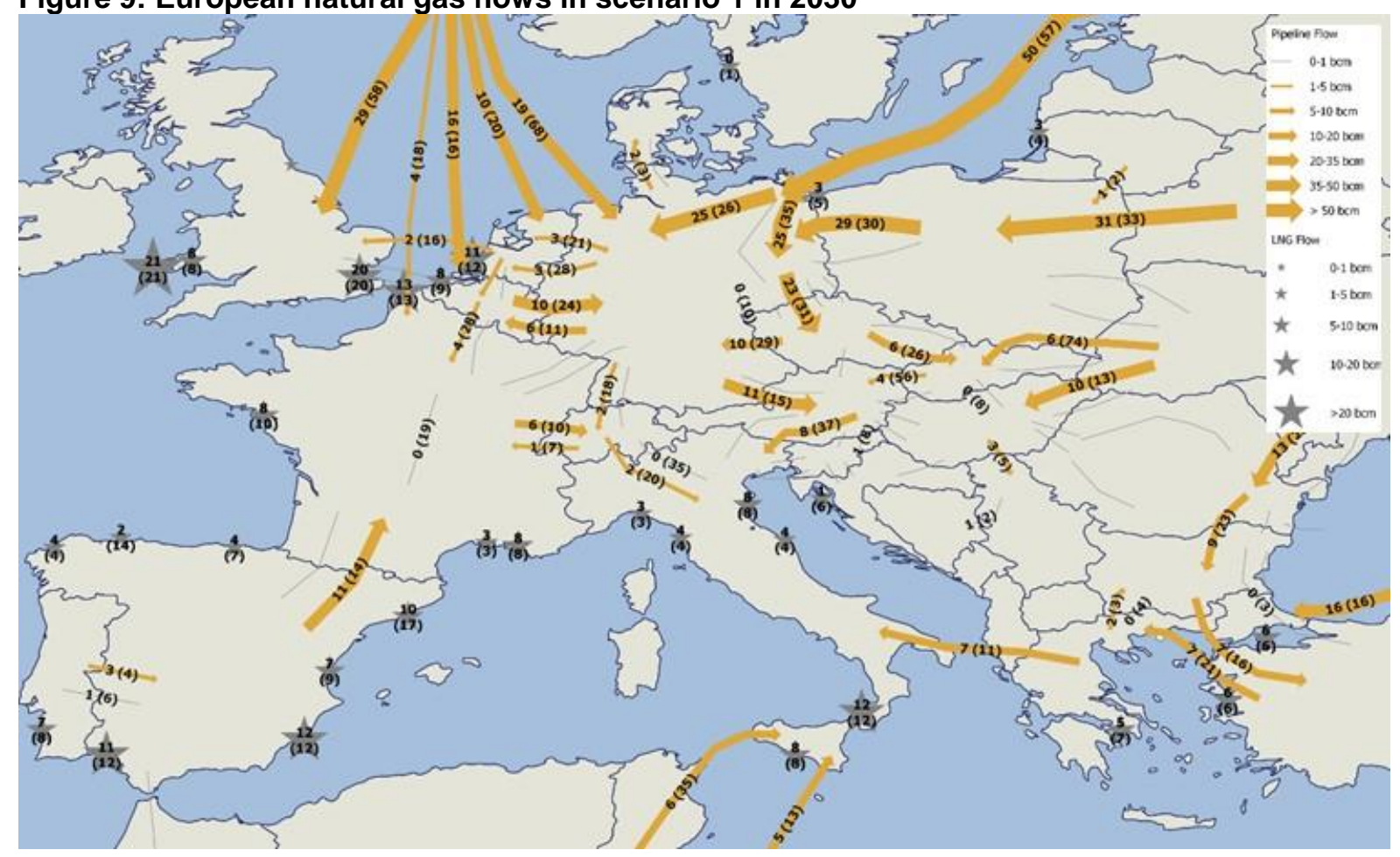

Source: ewi ER\&S - TIGER model

Figure illustrates that most of the European LNG import terminals are located in Western Europe. Therefore, countries in this region such as Portugal, Spain, France, Italy or the UK would show high LNG imports caused by a potential LNG oversupply. However, due to the lack of LNG regasification infrastructure and constraints in moving the gas from the West to the East, eastern European countries still record high Russian gas imports. Four main routes are used to bring Russian gas to Europe: Nord Stream ${ }^{19}$ via the Baltic Sea, the Yamal route via Belarus, the Ukrainian route, and Turkish Stream via the Black Sea. Under this scenario, where only $150 \mathrm{bcm}$ of Russian gas would reach the European market in 2030, a mere $29 \mathrm{bcm}$ of Russian gas would be transited via Ukraine which is the most expensive of the four routes.

Based on Figure, Figure shows the yearly average utilization rate of the European cross-border connections as well as those of the LNG import terminals in percentage terms. The value in the brackets represents the maximum utilization rate of the year's peak month. A generally high average utilization rate of LNG import terminals, especially in the UK, Belgium, the Netherlands and Italy, but

\footnotetext{
${ }^{19}$ We assume that OPAL can be used up to full technical capacity.
} 

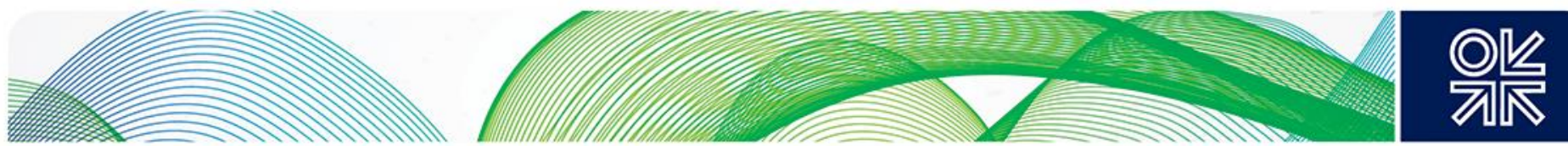

also in France, can be seen. Furthermore, the maximum utilization rate of the European LNG terminals illustrates the 'stressed' situation of LNG supply in this scenario. In 2030, there is at least one month in which nearly all European LNG terminals are fully utilized, even the projected new LNG facilities in Italy and Spain.

Pipeline supply to the European market is mainly characterized by low utilization rates; hence there would be enough spare capacity for alternative pipeline supply. However, high utilization of the Russian supply pipelines Nord Stream, Yamal and Turkish Stream is currently driven by high Ukrainian transit fees, the reason behind the Russian intention to bypass Ukraine.

Within the internal European market some bottlenecks occur. In the first joint OIES/ewi ER\&S paper ${ }^{20}$ the focus was on an analysis of historical gas flows and potential bottlenecks occurring between PEGNord and PEG-Sud ${ }^{21}$ in France, between NCG in Germany and CEGH in Austria, and between NCG in Germany and PSV in Italy (via Switzerland).

Figure 10: Natural gas infrastructure utilization in scenario 1 in 2030

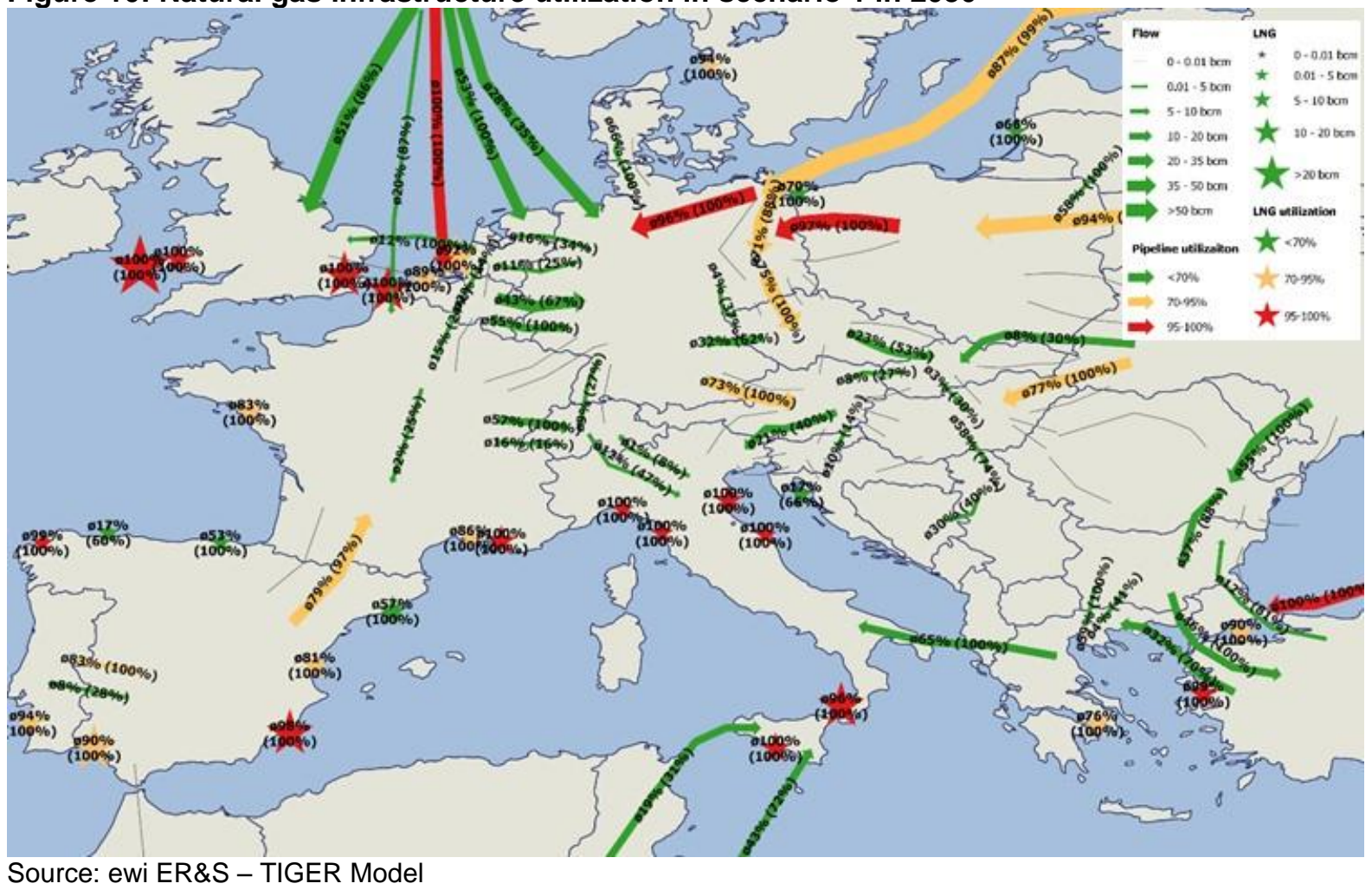

When looking at these three interconnections, the situation has partly changed in the scenario under consideration by 2030. The bottleneck in France, between PEG-Nord and PEG-Sud does not exist any longer. This is due to the fact that within the considered scenario whereby $225 \mathrm{bcm}$ of LNG would be imported in 2030, enough LNG would be imported into Southern France to prevent a potential bottleneck within the country. Additionally, Southern France would benefit from the investment into the

\footnotetext{
20 'European gas grid through the eye of the TIGER: investigating bottlenecks in pipeline flows by modelling history', B.

Petrovich, H. Rogers, H. Heckling, F. Weiser, NG 112, OIES \& EWI, 2016

${ }^{21}$ In 2015 the two market areas PEG-Sud and TIGF were pooled into one market area called Trading Region South (TRS).
} 

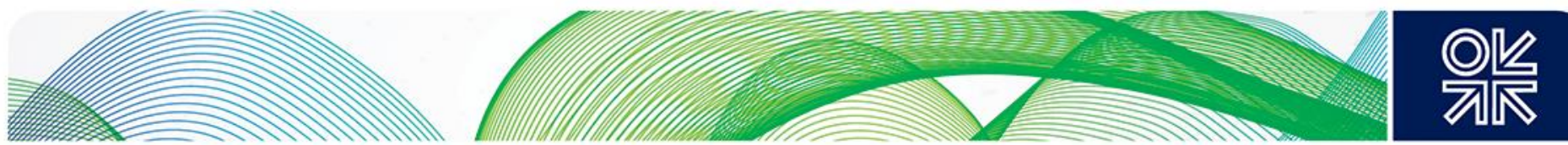

Midcat pipeline project which increases interconnectivity with Spain. By doubling cross-border capacity, southern France would be able to import additional LNG volumes from its western neighbour and this would further alleviate the need for north to south flows within France. In the considered scenario with high European LNG imports, the utilization of the Midcat pipeline is high, averaging 79 per cent and reaching 97 per cent during its peak month. This highlights the project's importance in a scenario in which low LNG prices incentivise high European LNG imports ${ }^{22}$.

The interconnection capacity between Germany and Austria is still highly utilized, as already observed in the historic analysis of the year $2014 .{ }^{23}$ On average the yearly utilization is 84 per cent in 2030. However, during peak times the utilization reaches 100 per cent. Figure 11 illustrates the utilization of the German-Austrian cross-border flow over the entire simulation horizon with a monthly granularity from 2017 to 2030. The blue dashed line depicts the cross-border flow capacity in the respective direction and shows the expansion of the interconnection capacity which takes place in $2018^{24}$. The yellow line shows the physical gas flow. It becomes clear that there is a flow from Germany to Austria only. Thus, in a scenario with high European LNG imports, Germany could be supplied by Russian and Norwegian gas from the North and LNG imports via the West. There is no need for additional imports from the South and hence reverse flows from Austria. However, the utilization is especially high during the summer months. This is driven by higher German consumption during the wintertime and hence a reduced re-export potential in the winter.

Figure 11: Cross-border flows of DE-AT in scenario 1 from 2017 to 2030

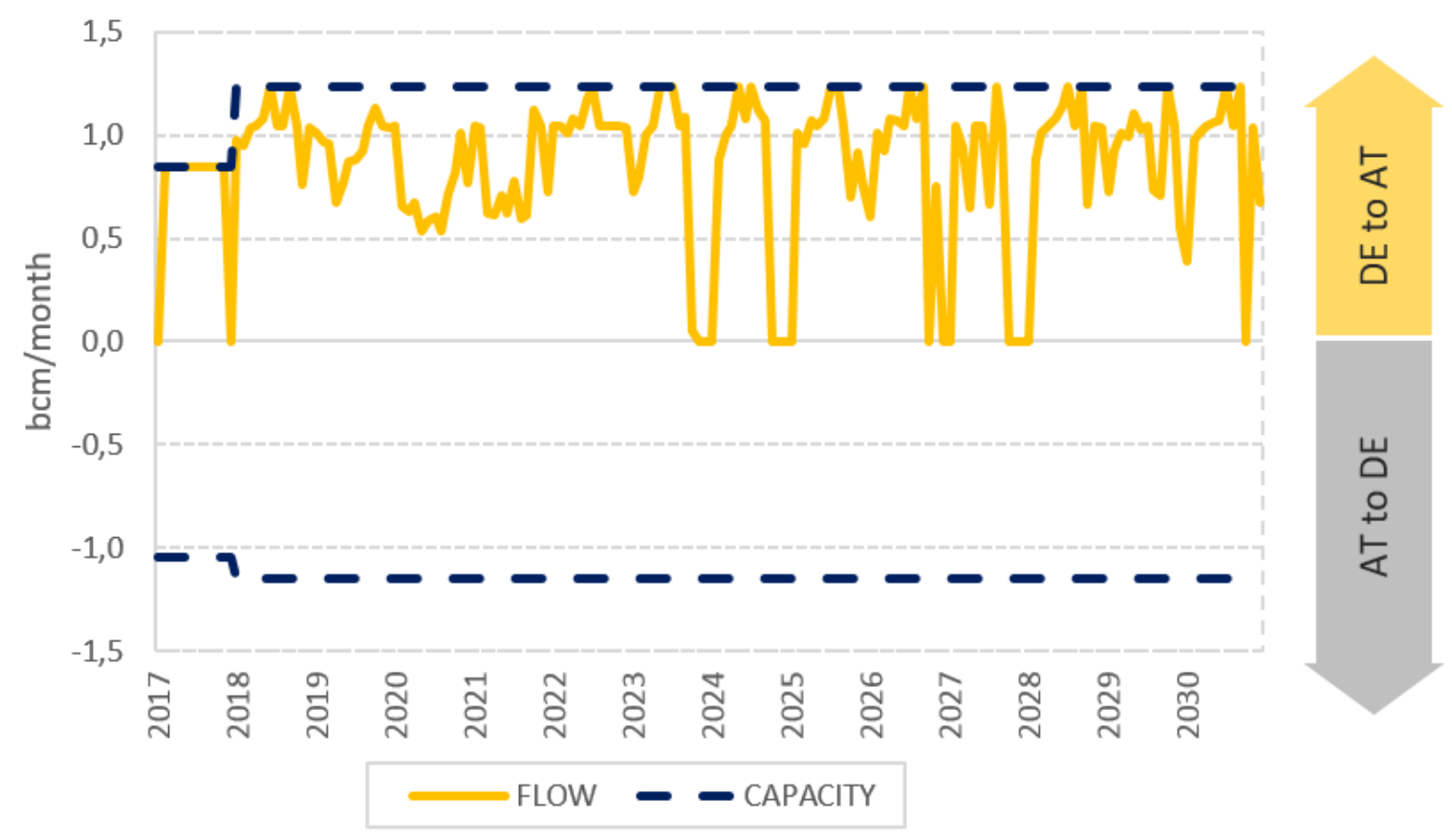

Source: ewi ER\&S - TIGER model

\footnotetext{
${ }^{22}$ Nonetheless it is important to stress the fact that this paper does not provide a cost-benefit analysis of the Midcat project and the consequential system enforcements required in the French grid. The paper assumes that the connection has been built and assesses to what extent the connection will be used assuming similar tariffs as today.

${ }^{23}$ 'European gas grid through the eye of the TIGER: investigating bottlenecks in pipeline flows by modelling history', B. Petrovich, H. Rogers, H. Heckling, F. Weiser, NG 112, OIES \& EWI, 2016

${ }^{24}$ Project MONACO from bayernets GmbH (see appendix, TYNDP 2017). However, TYNDP 2017 assumes the project commissioning in 2017. Bayernets $\mathrm{GmbH}$ dates the commissioning for 2018.
} 

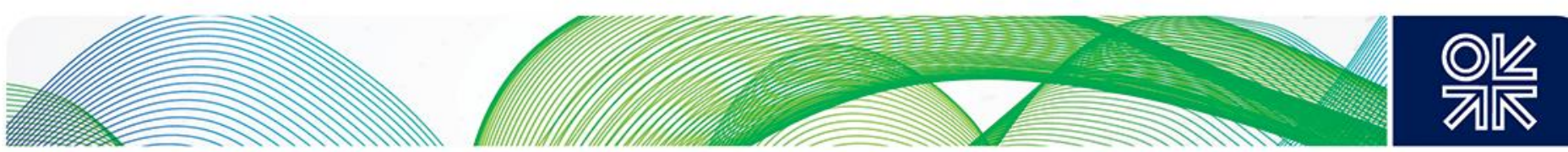

Finally, the first joint OIES/ewi ER\&S paper ${ }^{25}$ looked at the interconnection between Germany and Switzerland and the price differences between the German hub NCG and the Italian hub PSV. When looking at the year 2030 in the flow map in Figure it seems that this connection is of minor importance only. The utilization of the interconnection is on average 10 per cent and during its peak month only achieves 27 per cent. This low utilization is mainly driven by Italy's alternative supply options within the considered scenario. The figure shows that in 2030 , Italy is mainly supplied by LNG. Both the existing LNG terminals and also new terminals are fully utilized in 2030. Furthermore, the TAP pipeline that transports gas from the Caspian region via Turkey and Greece to Italy would also be fully utilized. This creates an incentive for low Italian natural gas imports from the North, via Switzerland or Austria. This differs from the historical situation in 2014 in which German and Italian prices showed a large price spread on some days, due to a non-physical bottleneck in Switzerland.

In addition, Figure 12 shows the utilization of German-Switzerland cross-border capacity in a monthly granularity over the entire simulation horizon. It illustrates that utilization is high until 2020, but, after 2020 the average utilization declines, driven by the commissioning of the TAP pipeline. Furthermore, the figure shows that there are no reverse flows via the expanded Transitgas pipeline from Switzerland to Germany. However, there are limited reverse flows via Transitgas from Italy via Switzerland to France ${ }^{26}$.

Figure 12: Cross-border flows of DE-CH in scenario 1 from 2017 to 2030

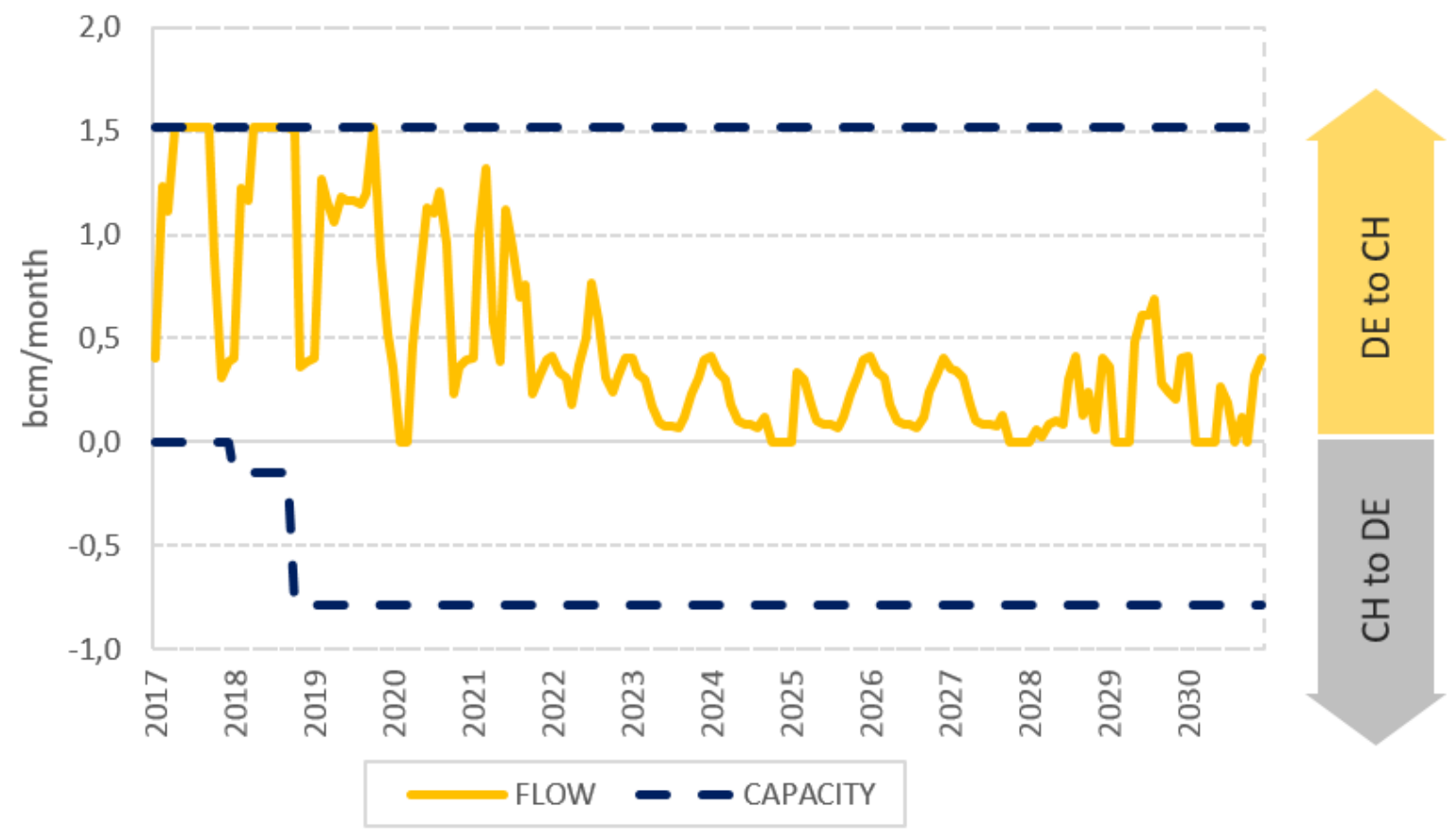

Source: ewi ER\&S - TIGER model

\section{Scenario 2: High Asian Demand with New LNG Projects in the mid 2020s}

The second simulated scenario assumes a high Asian demand and investments in global LNG liquefaction terminals in the mid-2020s. As a result of the high Asian demand, Europe might not

\footnotetext{
${ }^{25}$ OIES \& EWI (2015)

${ }^{26}$ Nonetheless it is important to stress the fact that this paper does not provide a cost-benefit analysis of the Transitgas project. The paper assumes that the connection has been built and assesses to what extent the connection will be used assuming similar tariffs as today. Other scenarios lead to a higher utilization of the pipeline. Furthermore, a daily simulation may also change the picture.
} 

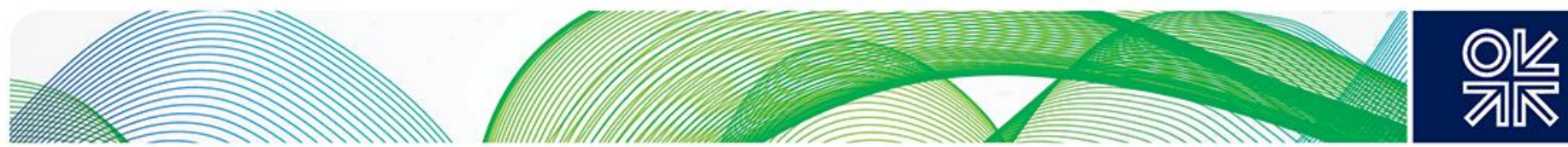

benefit from high future LNG import volumes because most of the additional supply would be absorbed by Asian countries. In this scenario, Russian gas supply would determine future European gas flows. In order to ensure that Russian volumes would reach the European market, the pipeline investments mentioned in Table 1 would be necessary. However, as mentioned above, the Russian pipeline project Nord Stream 2 that directly connects Russia and Germany is not part of the initial scenario simulation. It will be discussed separately at the end of this chapter.

Figure 13 shows the natural gas flows to and within the European natural gas market in 2030 . Compared to the first scenario, less natural gas is imported as LNG. Hence, there is a lower volume of gas transported from Western Europe to Central and Eastern Europe. However, due to higher imports of Russian gas there is a strong pan-European gas flow from East to West. All Russian supply routes are strongly utilized, including the route via Ukraine. Hence, in 2030 about $93 \mathrm{bcm}$ of natural gas would flow via Ukraine to its Western neighbours. In total, $255 \mathrm{bcm}$ of Russian natural gas is supplied to Europe in this scenario.

\section{Figure 13: European natural gas flows in scenario 2 in 2030}

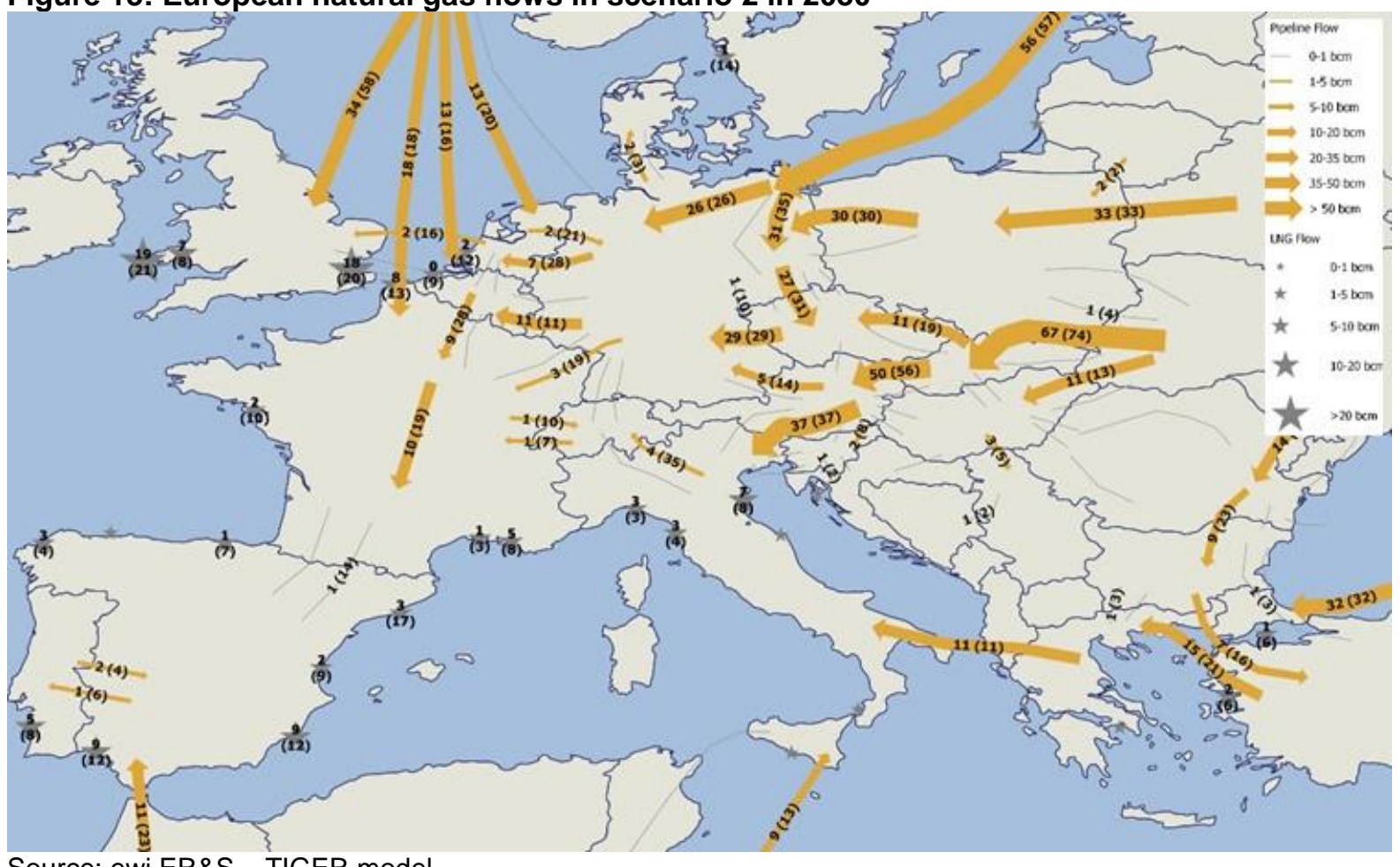

Source: ewi ER\&S - TIGER model

The utilization of the LNG import terminals in 2030 as well as the utilization of the import pipelines and the internal European pipelines in 2030 are shown in Figure 14. In line with the scenario definition, the LNG import terminal utilization is relatively low compared to the first scenario. However, the utilization of the Russian export pipelines is high.

Assuming that OPAL may be utilized at full capacity, the Nord Stream pipeline is fully utilized during the entire year. The same applies for the Russian pipelines Yamal and Turkish Stream. As already mentioned, even the Ukrainian transit route exhibits a high utilization. Its main exit to Slovakia is utilized at 91 per cent on average. There are also months in which the Ukrainian exits are fully utilized.

However, the large natural gas imports from Russia induce bottlenecks within the internal European market, which could lead to hub price disconnections. This applies especially to the route from Austria to Italy, where Russian gas transited via Ukraine and Slovakia reaches the Italian market. The crossborder capacity is on average utilized at 98 per cent in 2030. Furthermore, the cross-border 

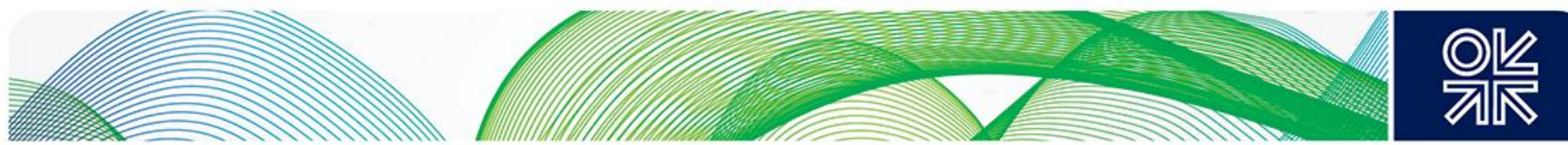

connection between the Czech Republic and Germany at the interconnection point Waidhaus, at which the gas enters the German MEGAL pipeline, is on average utilized at 99 per cent in 2030. Very high utilization figures are also observed for the cross-border connection between Germany and Belgium. High Russian gas imports, therefore, induce additional bottlenecks, in particular in Central Europe.

Figure 14: Natural gas infrastructure utilization in scenario 2 in 2030

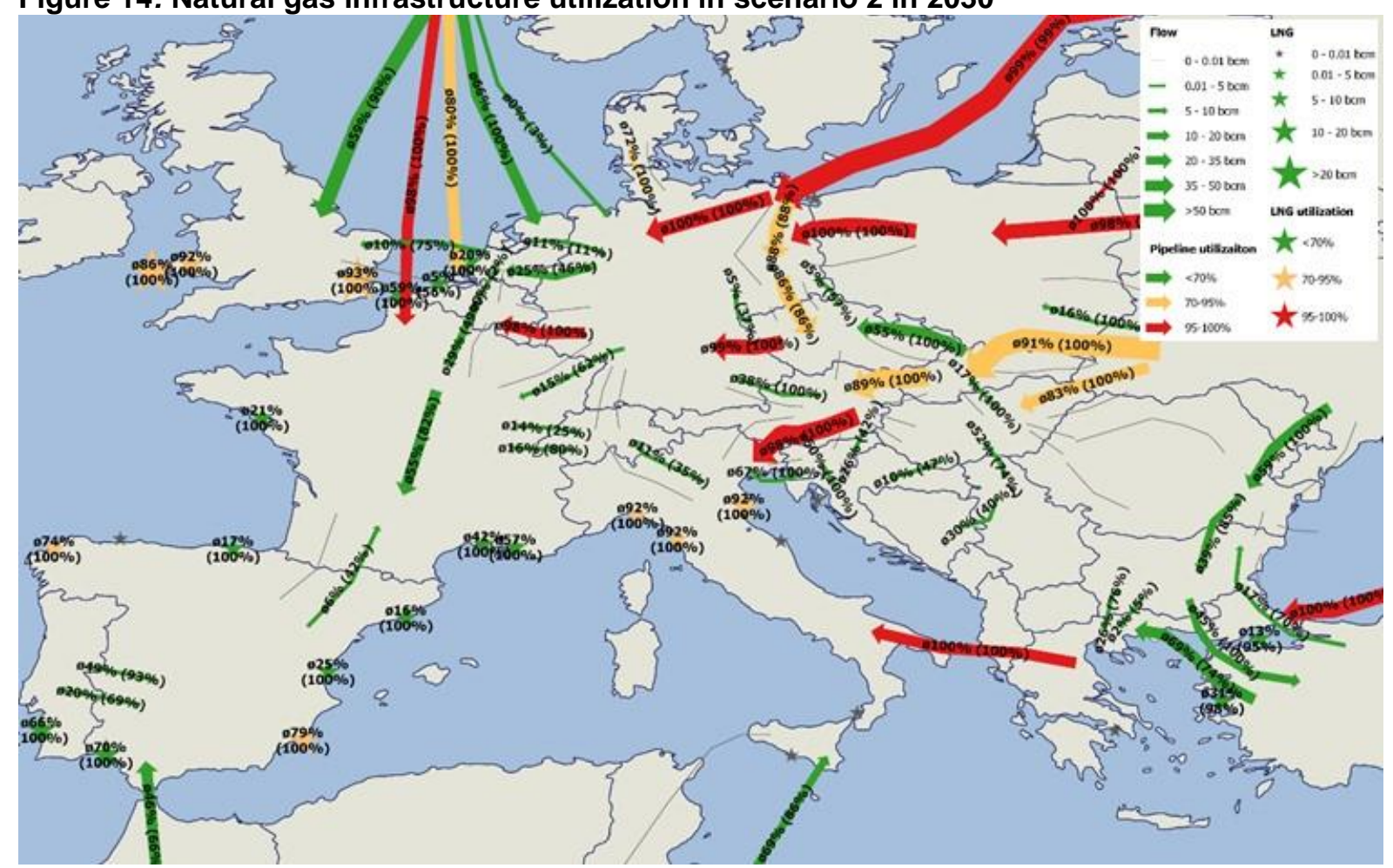

Source: ewi ER\&S - TIGER model

When looking again at the connections considered in the first joint OIES/ewi ER\&S paper ${ }^{27}$, the situation of the French bottleneck is similar to the first scenario. Even if in the second scenario less LNG enters the European market, the amounts are still sufficient to satisfy the southern French market with LNG. However, regarding the interconnections between Germany-Austria and GermanyItaly via Switzerland, different results occur compared to the first scenario.

In 2030, there is no gas flow from Germany to Austria and therefore no bottleneck in this direction. However, there is a gas flow in the opposite direction by which additional Russian gas is delivered via Austria to the NCG area in Southern Germany. In 2030 the interconnection would have an average utilization of 38 per cent and of 100 per cent at peak. This is mainly driven by the fact that the lowest cost supply route for Russian gas that is delivered via the Ukrainian route to Germany is the route via the Czech Republic at the border point of Waidhaus. Due to the fact that this route is bottlenecked as well, the gas volumes need an alternative way to enter the German market. However, as shown in Figure 15, this Austria-to-Germany flow first occurs in 2029. In the preceding years, the cross-border connection is highly utilized from Germany to Austria because at that time the route via the Czech Republic still has spare capacity.

${ }^{27}$ OIES \& EWI (2015) 

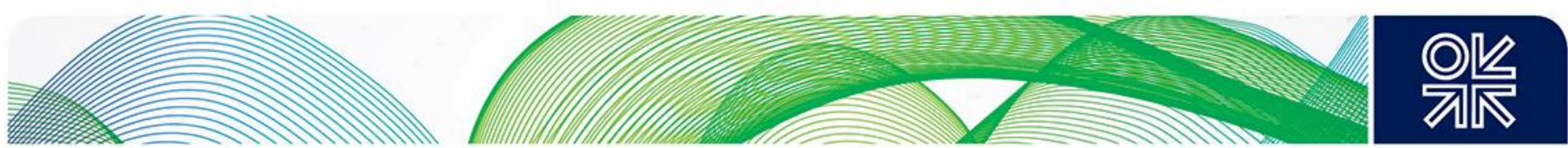

Figure 15: Cross border flows of DE-AT in scenario 2 from 2017 to 2030

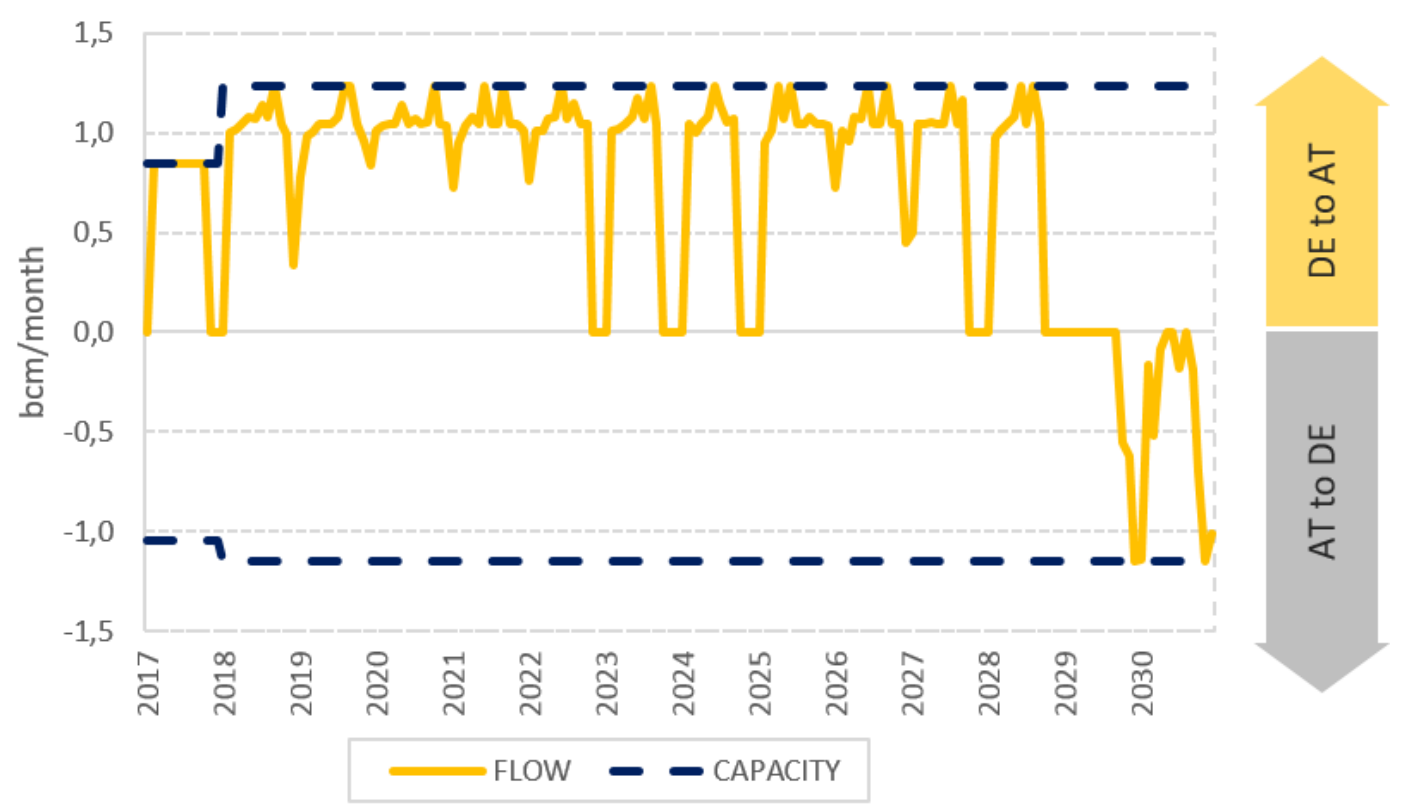

Source: ewi ER\&S - TIGER model

On the other hand, the cross-border connection between Germany and Switzerland records no gas flow in either direction from Switzerland in 2030. Swiss natural gas demand can be fully supplied from Italy. Additionally, there is also a re-export from Switzerland to France. This fits with the picture of pan-European gas flows from East to West, because it is Russian gas that is re-exported to France. However Figure 16, which depicts the cross-border flows between Germany and Switzerland, illustrates that there would be a gas flow from Germany to Switzerland before 2029. Again, as soon as the TAP pipeline comes online, there is a slump in utilization of this connection that eliminates the seasonal bottleneck, comparable to the first scenario.

Figure 16: Cross border flows of DE-CH in scenario 2 from 2017 to 2030

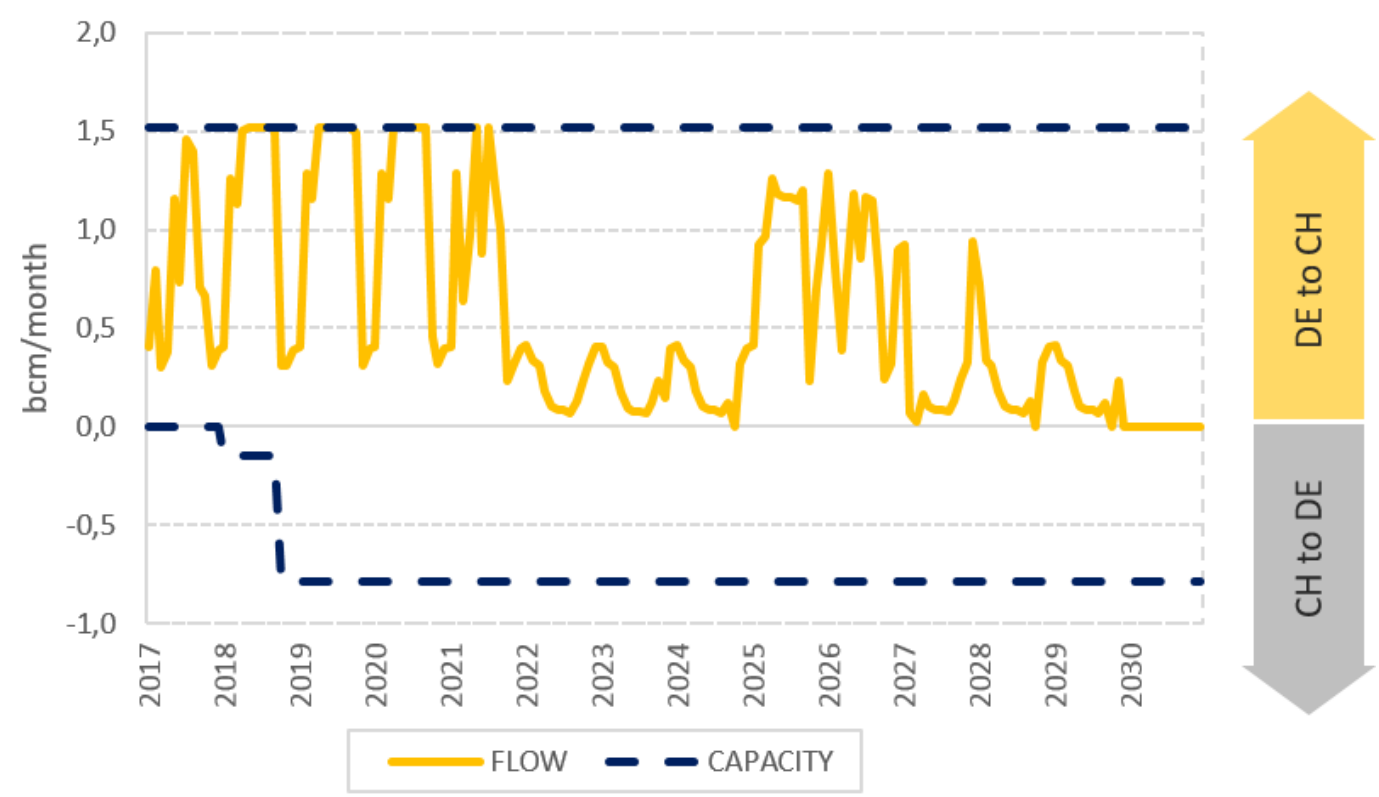

Source: ewi ER\&S - TIGER model 

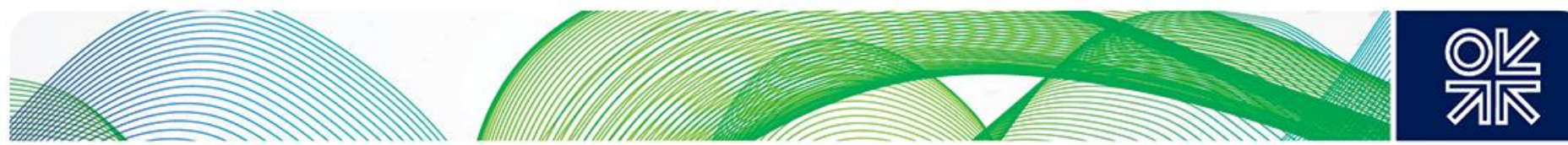

Finally, the impact of the pipeline project Nord Stream 2 on pan-European gas flows is analysed for the second scenario and the differences in gas flows are shown in Figure 17. The green arrows illustrate an increase in gas flows, the red arrows a decrease compared to the second scenario without Nord Stream 2. Therefore, Nord Stream 2 will mainly redirect Russian natural gas transits from the Ukrainian route. Gas flows via Ukraine and Slovakia to the Czech Republic would decrease. However, Russian gas arriving at the Nord Stream exit in Lubmin would be sent via the projected German pipeline EUGAL into the German Gas Pool market area and to the border of the Czech Republic. From the Czech Republic, the gas would be sent to Slovakia and the Central European Gas Hub in Austria. Furthermore, there would be also an increase in German re-exports to the Netherlands of $9 \mathrm{bcm}$ in 2030. The utilization of the Yamal pipeline would decrease when Nord Stream 2 is built reducing congestion between Poland and Germany.

Compared to the second scenario without Nord Stream 2, there are some changes with regard to pipeline utilization. The additional gas flows via Nord Stream 2 induce a bottleneck between the Czech Republic and Slovakia (see European map with pipeline utilization of the second scenario with Nord Stream 2 in the appendix). However, the former bottleneck between Austria and Italy is partly avoided and only occurs during peak times. The bottleneck between Germany and Belgium is not mitigated by the build-up of Nord Stream 2 .

\section{Figure 17: Differences in natural gas flows in scenario 2 in 2030 (if Nord Stream 2 and its} connecting pipelines are realized)

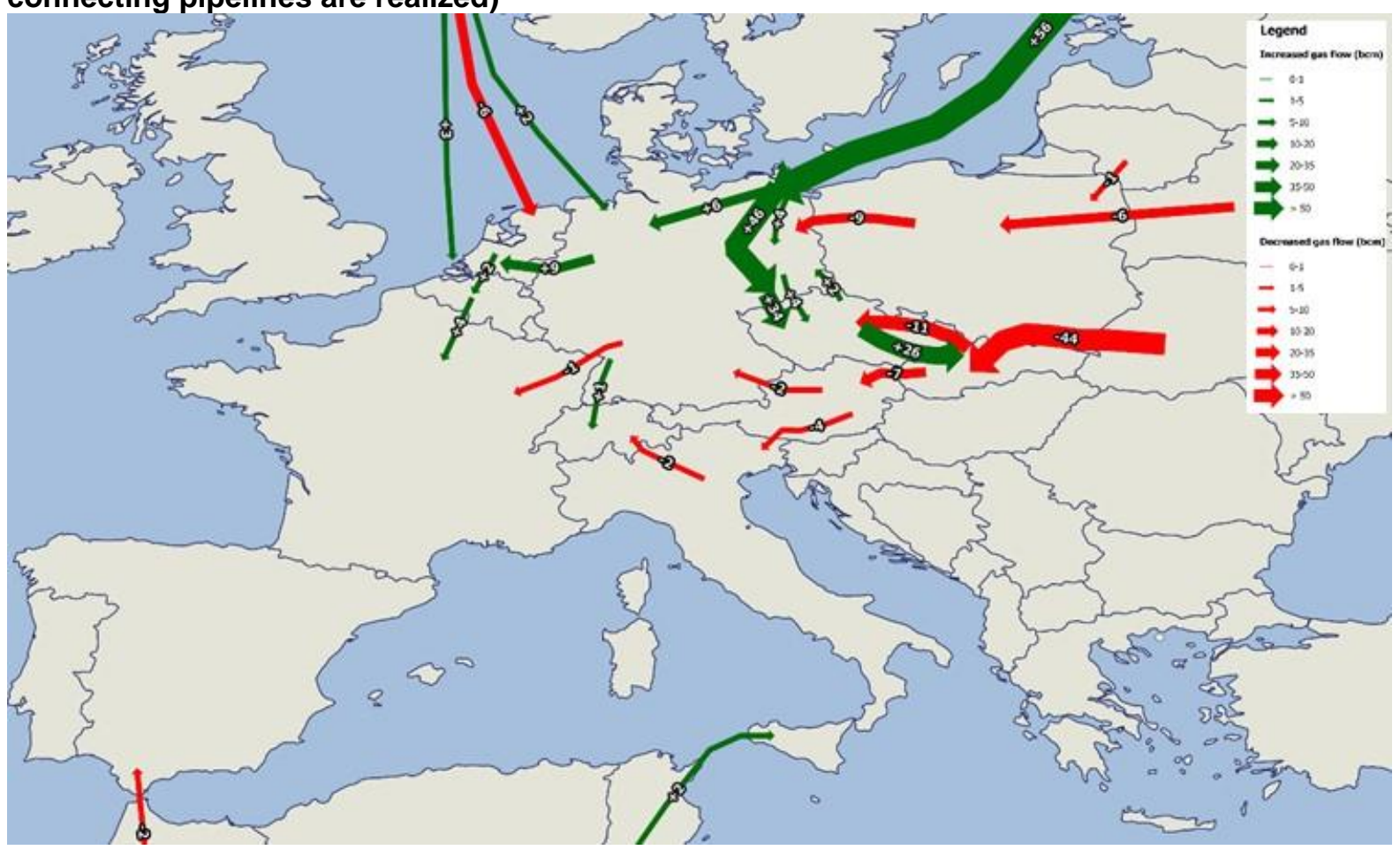

Source: ewi ER\&S - TIGER model 

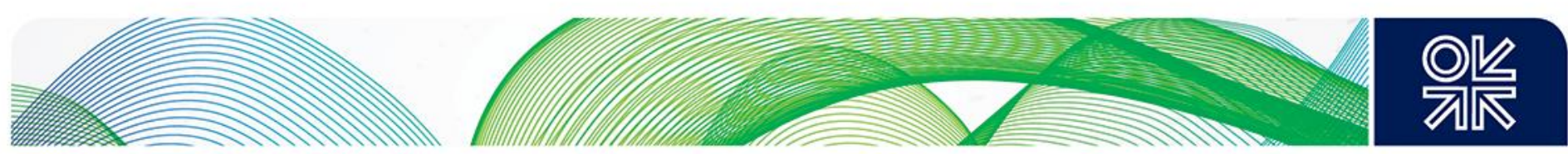

\section{Chapter 6 Conclusions}

The aim of this joint OIES-EWI study is to determine gas flow patterns and possible bottleneck problems within the European gas grid under two different but credible future demand/supply scenarios for the global gas market. The existence of a bottleneck between two market areas implies that their respective gas prices would decouple. Whether the investment to resolve a specific bottleneck is remunerated by subsequent price convergence is a moot point and beyond the scope of this paper.

In the first scenario, low Asian demand leads to a situation in which high LNG volumes are imported into the European market. In a second scenario, high Asian demand implies less LNG available for Europe and therefore higher pipeline import volumes from Russia.

Both scenarios are simulated with the European gas market model TIGER for the period 2017 to 2030, assuming that infrastructure projects which have already achieved FID are realized. In addition, in the scenario with low Asian demand, some new European LNG regas projects are assumed to come online before 2030. By contrast, in the scenario with high Asian demand additional import pipelines for Russian gas are modelled (with and without the Nord Stream 2 pipeline project). This additional infrastructure consists of planned projects that at present have a non-FID status. If such infrastructures are not realized, this would result in at best non-optimal flows (hub price differentials increased by higher transport costs), through to a situation where new bottlenecks create pockets of demand susceptible to very high prices, and in the worst case, insufficient gas supply requiring demand to be met by alternative fuels.

Our assumption for European demand outlook is rather bearish and constant across the two scenarios: European gas consumption is assumed to stay flat until 2020 and then to increase slightly due to assumed shutdown of coal and nuclear plants and a slowing in the pace of renewable investment in the 2020s.

All transmission entry/exit fees are assumed to be equal to today's levels and remain constant until 2030. The TIGER model minimizes the total transport costs within the European natural gas markets, subject to capacity constraints.

The two supply scenarios both imply a significant change with respect to the recently prevailing flows and with respect to current bottleneck problems in the grid. In particular, against the assumed background of increasing LNG imports compared to recent levels (raising from $52 \mathrm{bcma}$ in 2015 to 225 and 110 bcma by 2030 in the first and second scenario, respectively), the historically observed bottleneck within France ceases to exist in both scenarios, even under the assumption that the PEGN-TRS interconnection capacity is not expanded. This should result in a single wholesale price for traded gas in France and in the disappearance of price delinkages between PEGN and TRS, which have occurred frequently since 2012 in times of scarce LNG supply in Southern France and LNG re-exports from Spain. Additionally, in both simulations, Southern France would benefit from the assumed start-up in 2021 of the $7 \mathrm{bcm} / \mathrm{a}$ Midcat pipeline project which increases the interconnectivity with Spain: by doubling the cross-border capacity, Southern France would be able to import additional LNG volumes from its western neighbour, while no Spanish imports from France occur in either of the two scenarios, as opposed to what we have observed in recent years. However, the Midcat route is highly utilized, (and at times is close to full capacity), only in the high European LNG import scenarios, while under the other scenario, load factors for the Spain-to-France transmission capacity are moderate.

Although under both scenarios the French congestion issue is resolved, overall the two contrasting scenarios lead to very different cost-minimizing flow patterns within the European grid. 

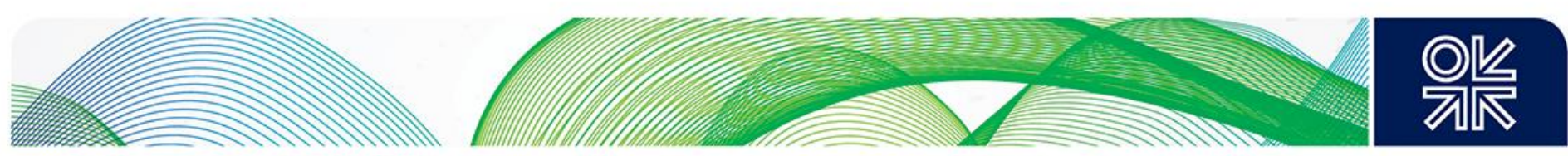

Assuming low Asian demand (high European LNG imports), gas mostly flows from the West (where most of the existing and FID regasification terminals are located) to the East, and virtually all European LNG imports terminals (including the planned ones) are heavily utilized. In the high Asian demand case (more modest European LNG imports) a strong pan-European gas flow from East to West emerges and European regasification facilities have lower utilization rates, with the exception of those in the UK and Italy. LNG imports in both scenarios increase significantly compared to today's level.

Overall, the scenario with high Asian demand (low European LNG imports) seems more problematic from a pipeline bottleneck perspective, because a substantial part of the transmission capacity in the Eastern, Central and Southern part of the Continent would be utilized at peak levels. This would lead to physical congestion which may result in disconnections between traded gas prices at hubs in the respective regions. In contrast in the low Asian demand (high European LNG imports) scenario, the European grid is characterized by a generally low pipeline utilization (with some exceptions in Eastern Europe).

More specifically, in the scenario featuring higher Russian imports to Europe, all Russian existing supply routes would be strongly utilized, including the route via Ukraine, and new bottlenecks (which we do not observe today) would emerge in Eastern and Central Europe. These would occur between the Czech Republic and Germany, on the route from Austria to Italy and from Germany to Belgium. Additionally, transmission capacity between Germany and Austria is expected to be used heavily, first westwards and then eastwards. In fact, while the historically observed physical bottleneck from Germany to Austria is solved only at the very end of the simulation period, in the late 2020s additional Russian gas starts to be delivered via Austria to Southern Germany. This route is expected to be saturated for some periods, which coincide with the interconnection point Waidhaus, linking the Czech and German market, also being congested. While France and the Iberian Peninsula would not experience any bottlenecks, in Italy lower LNG terminal send-outs would lead to heavy utilization and physical congestion of the TAP and of import capacity from Austria.

In contrast, the higher European LNG imports scenario would create fewer pipeline bottlenecks in Central and Southern Europe. Assuming high LNG imports to Europe, the historically observed physical bottleneck on the route from Germany to Austria would start to be alleviated from 2020 onwards: in this scenario, Germany would be fully supplied by Russian and Norwegian gas from the North and LNG imports from the West. The German market would have no reason to import additional volumes from Austria, and would also re-export some of its supply to the Austrian Virtual Trading Point at times of lower domestic consumption using the bidirectional WAG pipeline.

High LNG imports and low Russian supply would also result in Italy being mainly supplied by a combination of LNG and Caspian gas, with the projected TAP pipeline experiencing high load factors without being physically saturated. Thus, assuming the realization of additional LNG regasification capacity in Italy and the decrease in Algerian pipeline imports, lower Italian natural gas imports from the North, via Switzerland or Austria, compared to today, should occur and, consequently, the utilization of the interconnection between Germany and Switzerland, in the direction of Italy, would decrease after 2020, leaving ample spare capacity to conduct arbitrage between North West Europe and Italy.

Interestingly, however, even in the high European LNG import scenario, the utilization rate of import pipelines from Russia to eastern European countries would still remain at peak levels, due to the lack of $L N G$ regasification infrastructure and constraints in moving the gas from the West to the East. This would stress the Yamal route, the Nordstream/NEL route, and, to a lesser extent, the transmission capacity to Hungary and from Germany to the Czech Republic. The Ukraine route would be underutilized in this scenario: only 30 bcma of Russian gas would transit via Ukraine in 2030 (which represents less than one third compared to the scenario with high Russian imports and no realization of the Nord Stream 2). 

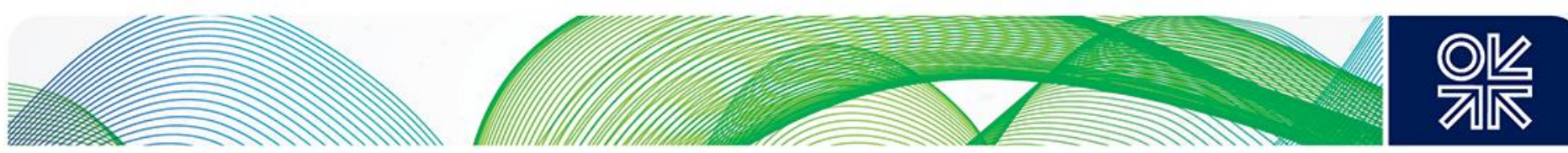

Our sensitivity analysis also suggests that, in a low European LNG import scenario, the realization of the Nord Stream 2 would substantially change the flow pattern in Eastern Europe but would not cure all the above mentioned bottlenecks. In particular, Nord Stream 2 should mainly redirect Russian natural gas transit volumes from the Ukrainian route, whose utilization rate would reduce significantly, and additionally cause an increase in German re-exports to the Netherlands. Nord Stream 2 would create a new bottleneck between the Czech Republic and Slovakia, but would partly avoid the congestion between Austria and Italy, which would only occur during peak times, and between Poland and Germany.

Although the present study does not provide a cost-benefit analysis of the planned infrastructure projects, it offers insights for decisions by regulators and system operators in their deliberations on pipeline system expansion decisions. Depending on which scenario starts to unfold, grid bottlenecks can appear or be solved in Central, Western and Southern Europe. While some tensions in the East are to be expected in each of the two scenarios, these are more significant in the case where the European gas supply mix is more reliant on Russian volumes in the future. 

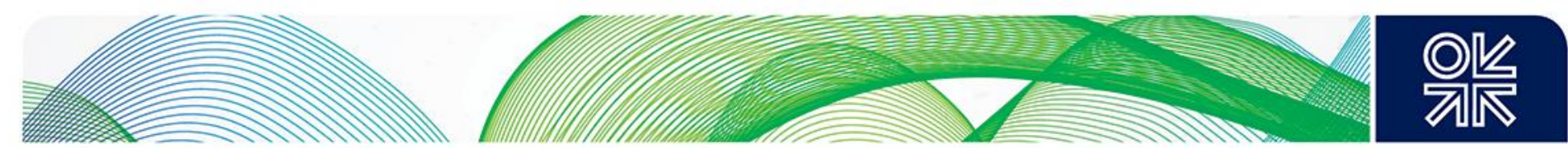

\section{Appendix}

\section{Description of the TIGER Model}

The TIGER model introduced by Lochner and Bothe (2007) is a European gas infrastructure and dispatch model. TIGER is capable of simulating natural gas trade as well as physical flows and therefore the utilization of all major elements of the European gas infrastructure (high pressure transport pipelines, LNG import terminals, and natural gas storage). Methodologically, TIGER is a linear network flow model consisting of nodes and edges. Nodes represent locations in the European gas infrastructure whereas edges represent pipeline connections.

\section{Figure 18: Tiger Model Overview}

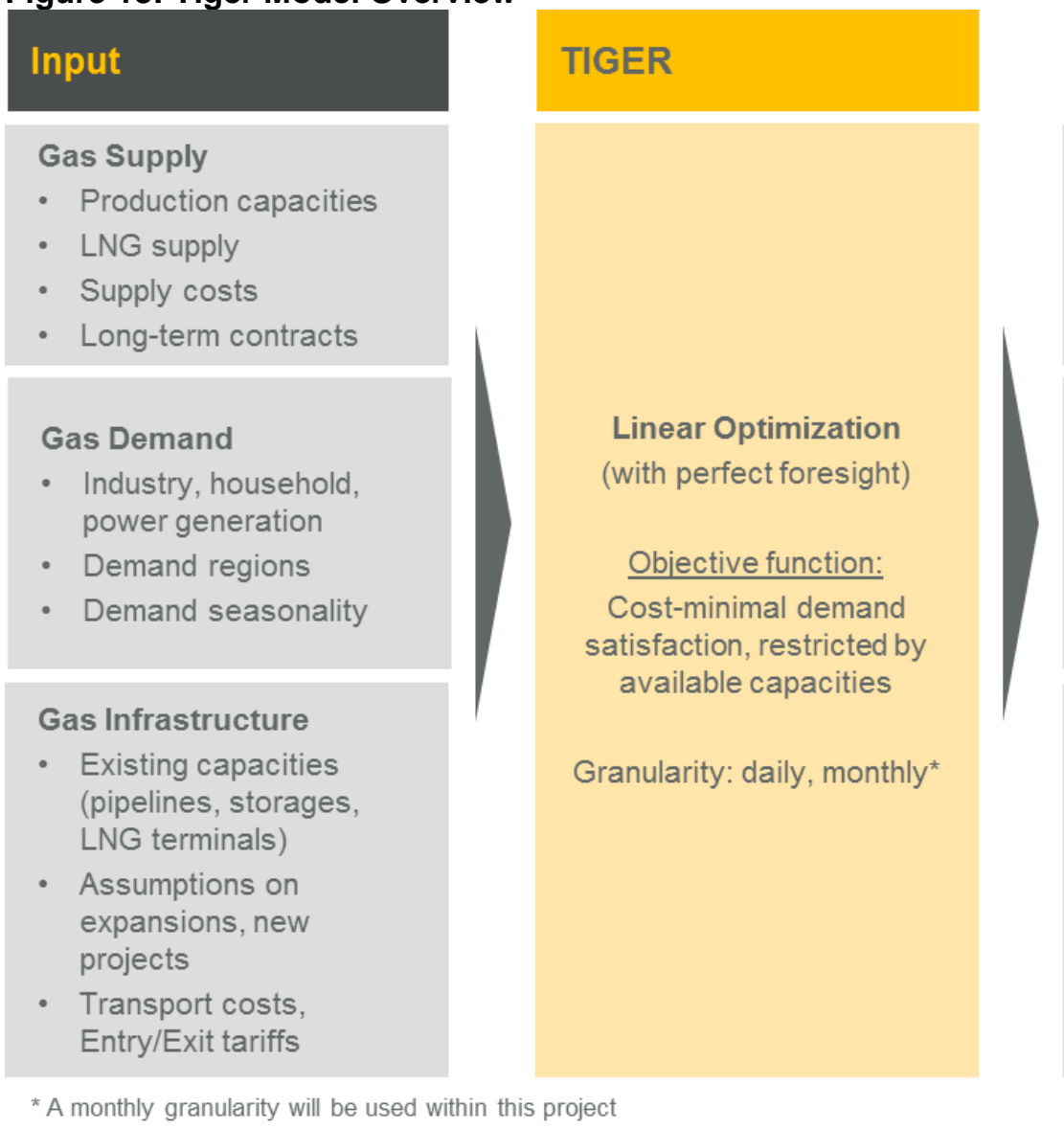

\section{Output}

- European natural gas flows (trade flows and physical flows)

- Cost minimal satisfaction of gas demand

- Infrastructure asset utilization (Pipelines, Storages, LNG)

- Local natural gas supply/import costs

- Hub-prices

Source: ewi ER\&S (2016)

Figure 18 gives an overview of the TIGER model. It illustrates the required input parameters, the optimization problem with its objective function as well as the output derived from the resolution of the optimization problem. On the input side, the model is provided with assumptions about natural gas demand, natural gas supply and the natural gas infrastructure. Based on historic data, country and sector specific demand projections are broken down into monthly, regionalized demand profiles to ensure a realistic distribution of natural gas demand over area and time. In addition, assumptions about the future gas supply of Europe can be specified (indigenous production, exporters' production capacities, and commodity prices or supply costs at the border). For existing infrastructure elements, technical characteristics are given as exogenous parameters. Apart from the existing infrastructure, 

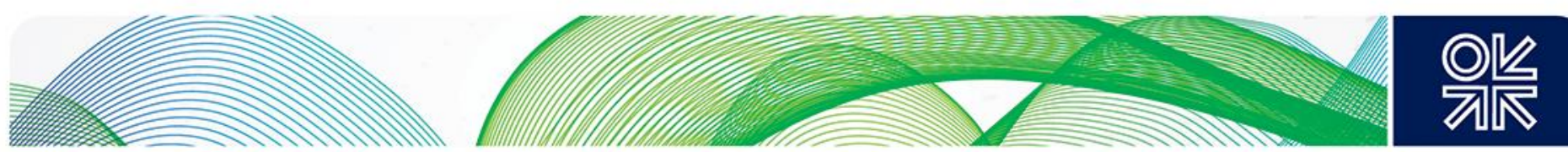

model inputs include assumptions on new projects regarding LNG import terminals, pipelines and natural gas storages which become available for optimization at the respective future points in time.

The TIGER model is formulated as a linear optimization problem. The objective function of the problem is the minimization of the total costs of the natural gas supply and transport system, while meeting regionalized demand. Costs include commodity, transportation (based on entry/exit tariffs) and, where applicable, regasification and storage costs. The cost optimization, with a monthly or daily granularity, takes place subject to the restrictions of maximum available supply, demand which has to be satisfied, and the technical constraints of available transport, LNG and storage infrastructure. Decision variables for the model are the natural gas flows on each pipeline, inflows to and outflows from storages, and regasification at LNG terminals. Due to storages, an inter-temporal optimization takes place. Since TIGER does not consider uncertainty with respect to its inputs, it is a perfect foresight model.

\section{Figure 19: Modelled natural gas infrastructure in the TIGER model (Schematic)}

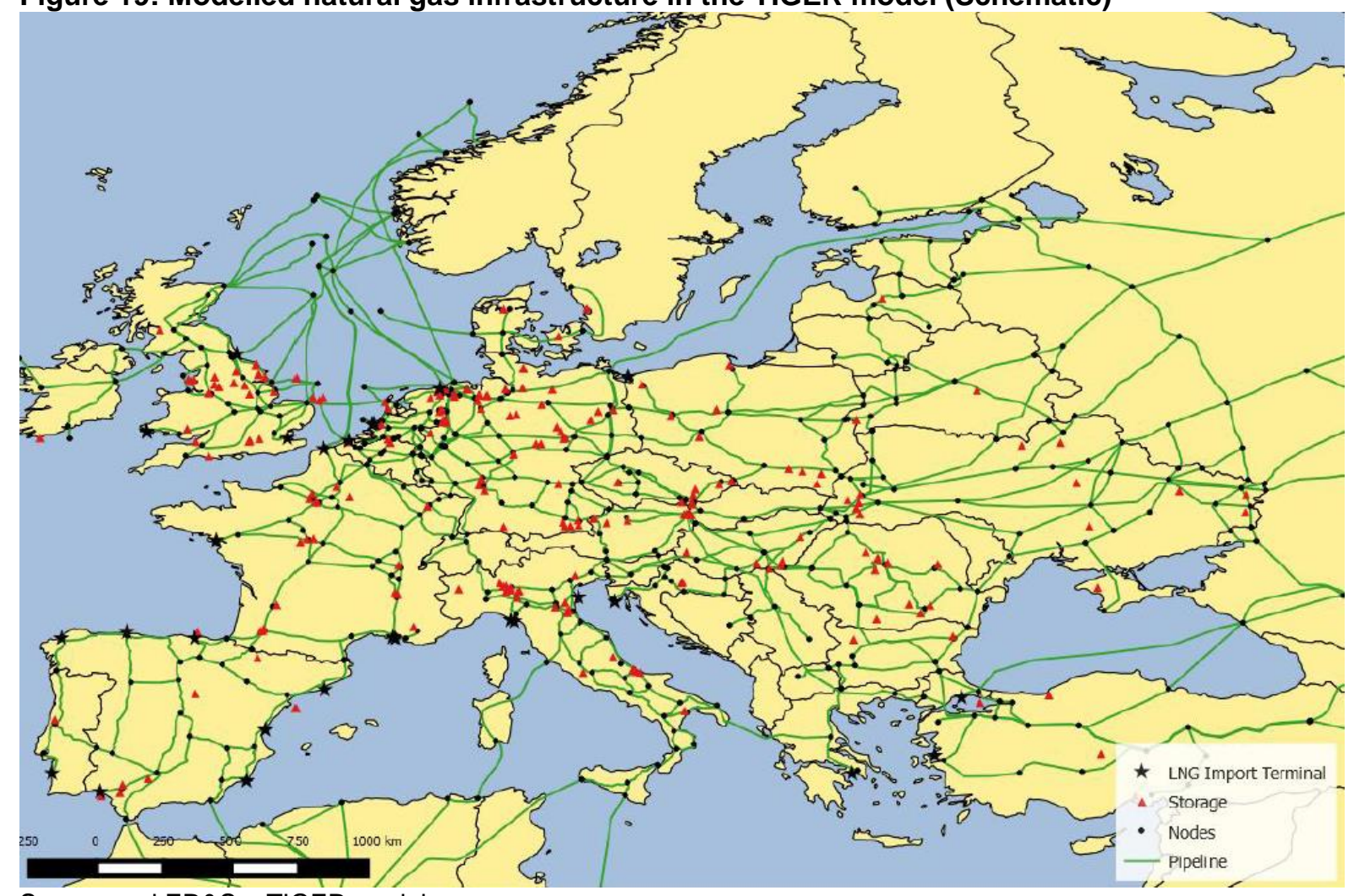

Source: ewi ER\&S - TIGER model 

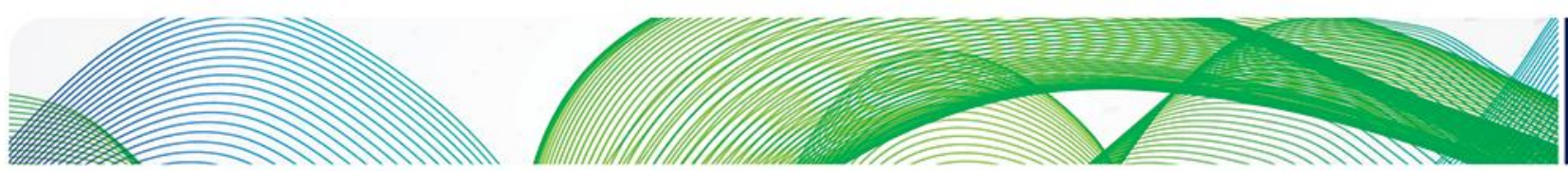

\section{O지소}

Infrastructure utilization in scenario 2 with Nord Stream

Figure 20: Infrastructure utilization in scenario 2 with Nord Stream 2 in 2030

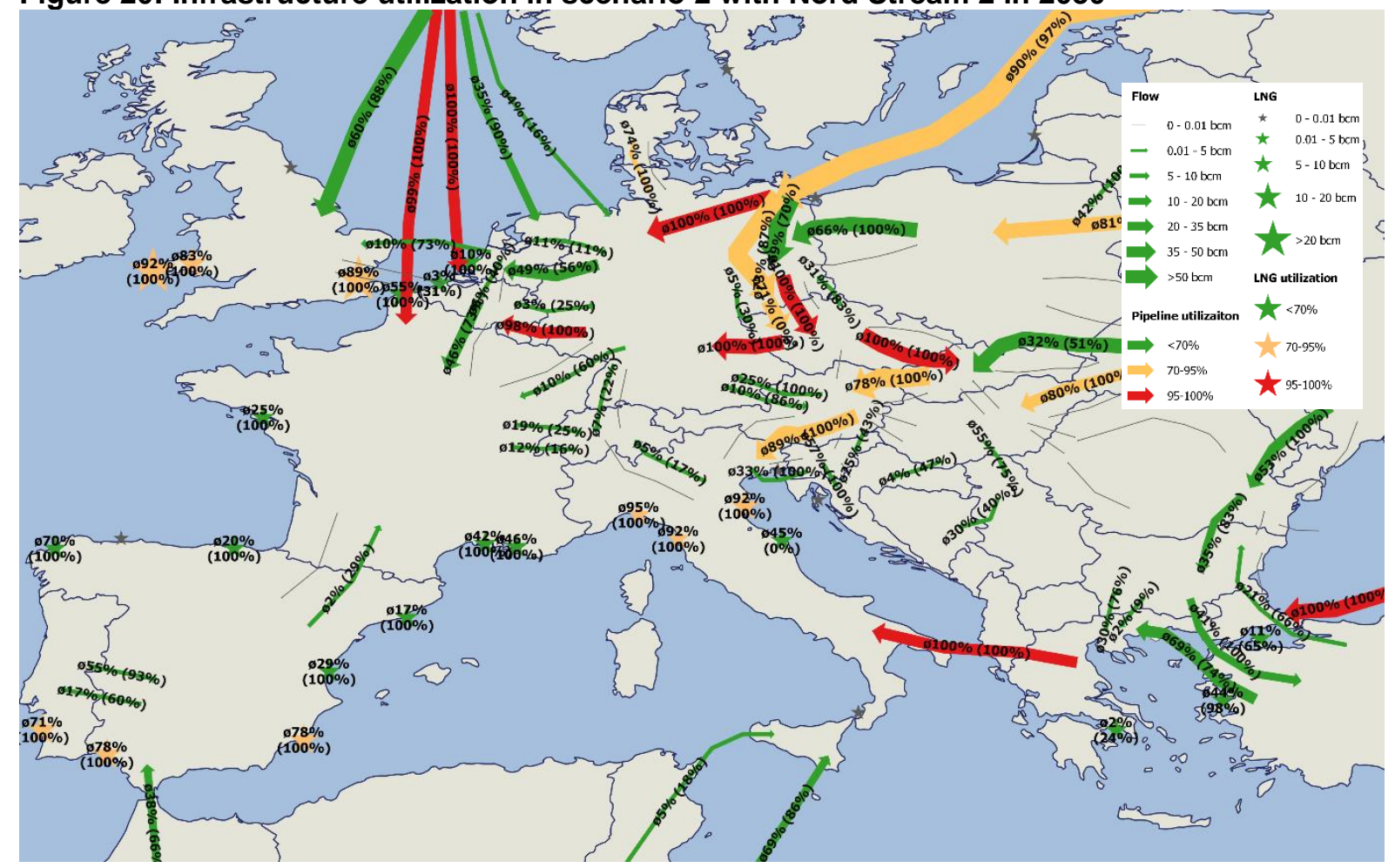

Source: ewi ER\&S - TIGER model 


\begin{tabular}{|c|c|c|c|c|c|}
\hline Type & Code & Name & Promoter & $\begin{array}{l}\text { Commissioning } \\
\text { Year }\end{array}$ & Section \\
\hline $\begin{array}{l}\text { Pipeline } \\
\text { including } \\
\text { CS }\end{array}$ & $\begin{array}{l}\text { TRA- } \\
\text { F-029 }\end{array}$ & $\begin{array}{l}\text { Romania-Bulgaria } \\
\text { Interconnection (EEPR- } \\
\text { 2009-INTg-RO-BG) }\end{array}$ & $\begin{array}{l}\text { SNTGN Transgaz } \\
\text { SA }\end{array}$ & 2016 & Giurgiu-Ruse \\
\hline $\begin{array}{l}\text { Pipeline } \\
\text { including } \\
\text { CS }\end{array}$ & $\begin{array}{l}\text { TRA- } \\
\text { F- } \\
1047\end{array}$ & Exit Capacity Budince & eustream, a.s. & 2016 & Exit Budince \\
\hline $\begin{array}{l}\text { Pipeline } \\
\text { including } \\
\text { CS }\end{array}$ & $\begin{array}{l}\text { TRA- } \\
\text { F-241 }\end{array}$ & $\begin{array}{l}\text { MONACO section phase } \\
\text { I (Burghausen-Finsing) }\end{array}$ & bayernets $\mathrm{GmbH}$ & $2017^{28}$ & $\begin{array}{l}\text { Burghausen- } \\
\text { Finsing }\end{array}$ \\
\hline $\begin{array}{l}\text { Pipeline } \\
\text { including } \\
\text { CS }\end{array}$ & $\begin{array}{l}\text { TRA- } \\
\text { F-291 }\end{array}$ & $\begin{array}{l}\text { NOWAL - Nord West } \\
\text { Anbindungsleitung }\end{array}$ & $\begin{array}{l}\text { GASCADE } \\
\text { Gastransport GmbH }\end{array}$ & 2017 & Rehden-Drohne \\
\hline $\begin{array}{l}\text { Pipeline } \\
\text { including } \\
\text { CS }\end{array}$ & $\begin{array}{l}\text { TRA- } \\
\text { F-334 }\end{array}$ & $\begin{array}{l}\text { Compressor station } 1 \text { at } \\
\text { the Croatian gas } \\
\text { transmission system }\end{array}$ & Plinacro Ltd & 2017 & \\
\hline $\begin{array}{l}\text { Pipeline } \\
\text { including } \\
\text { CS }\end{array}$ & $\begin{array}{l}\text { TRA- } \\
\text { F-43 }\end{array}$ & Val de Saône project & GRTgaz & 2018 & Bourgogne \\
\hline $\begin{array}{l}\text { Pipeline } \\
\text { including } \\
\text { CS }\end{array}$ & $\begin{array}{l}\text { TRA- } \\
\text { F-43 }\end{array}$ & Val de Saône project & GRTgaz & 2018 & Etrez CS \\
\hline $\begin{array}{l}\text { Pipeline } \\
\text { including } \\
\text { CS }\end{array}$ & $\begin{array}{l}\text { TRA- } \\
\text { F-43 }\end{array}$ & Val de Saône project & GRTgaz & 2018 & Palleau CS \\
\hline $\begin{array}{l}\text { Pipeline } \\
\text { including } \\
\text { CS }\end{array}$ & $\begin{array}{l}\text { TRA- } \\
\text { F-43 }\end{array}$ & Val de Saône project & GRTgaz & 2018 & Voisines CS \\
\hline $\begin{array}{l}\text { Pipeline } \\
\text { including } \\
\text { CS }\end{array}$ & $\begin{array}{l}\text { TRA- } \\
\text { F-45 }\end{array}$ & $\begin{array}{l}\text { Reverse capacity from } \\
\mathrm{CH} \text { to FR at Oltingue }\end{array}$ & GRTgaz & 2018 & $\begin{array}{l}\text { Oltingue } \\
\text { interconnection } \\
\text { station }\end{array}$ \\
\hline $\begin{array}{l}\text { Pipeline } \\
\text { including } \\
\text { CS }\end{array}$ & $\begin{array}{l}\text { TRA- } \\
\text { F-45 }\end{array}$ & $\begin{array}{l}\text { Reverse capacity from } \\
\mathrm{CH} \text { to FR at Oltingue }\end{array}$ & GRTgaz & 2018 & Morelmaison CS \\
\hline $\begin{array}{l}\text { Pipeline } \\
\text { including } \\
\text { CS }\end{array}$ & $\begin{array}{l}\text { TRA- } \\
\text { F-221 }\end{array}$ & $\begin{array}{l}\text { TANAP - Trans Anatolian } \\
\text { Natural Gas Pipeline } \\
\text { Project }\end{array}$ & $\begin{array}{l}\text { SOCAR (The State } \\
\text { Oil Company of the } \\
\text { Azerbaijan } \\
\text { Republic) }\end{array}$ & 2018 & $\begin{array}{l}\text { Georgia/Turkey } \\
\text { border- Eskishehir }\end{array}$ \\
\hline
\end{tabular}

\footnotetext{
${ }^{28}$ Bayernets GmbH changed commissioning to 2018 (http://monaco.bayernets.de/)
} 


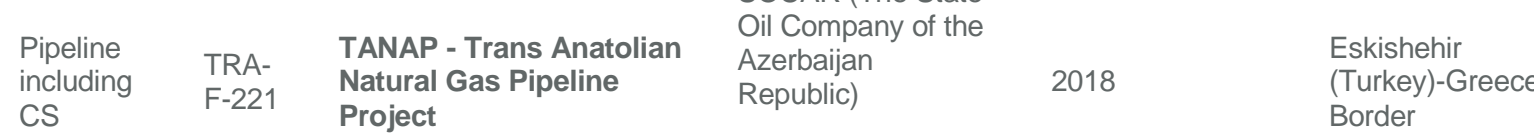

SOCAR (The State

Oil Company of the

Republic)

Project
Border

\begin{tabular}{|c|c|c|c|c|c|}
\hline $\begin{array}{l}\text { Pipeline } \\
\text { including } \\
\text { CS }\end{array}$ & $\begin{array}{l}\text { TRA- } \\
\text { F-337 }\end{array}$ & CS Rothenstadt & $\begin{array}{l}\text { GRTgaz } \\
\text { Deutschland } \mathrm{GmbH}\end{array}$ & 2018 & $\begin{array}{l}\text { MEGAL near } \\
\text { Weiden in der } \\
\text { Oberpfalz }\end{array}$ \\
\hline $\begin{array}{l}\text { Pipeline } \\
\text { including } \\
\text { CS }\end{array}$ & $\begin{array}{l}\text { TRA- } \\
\text { F-214 }\end{array}$ & $\begin{array}{l}\text { Support to the North } \\
\text { West market and } \\
\text { bidirectional cross- } \\
\text { border flows }\end{array}$ & $\begin{array}{l}\text { Snam Rete Gas } \\
\text { S.p.A. }\end{array}$ & 2018 & Section 1 \\
\hline $\begin{array}{l}\text { Pipeline } \\
\text { including } \\
\text { CS }\end{array}$ & $\begin{array}{l}\text { TRA- } \\
\text { F-214 }\end{array}$ & $\begin{array}{l}\text { Support to the North } \\
\text { West market and } \\
\text { bidirectional cross- } \\
\text { border flows }\end{array}$ & $\begin{array}{l}\text { Snam Rete Gas } \\
\text { S.p.A. }\end{array}$ & 2018 & Section 2 \\
\hline $\begin{array}{l}\text { Pipeline } \\
\text { including } \\
\text { CS }\end{array}$ & $\begin{array}{l}\text { TRA- } \\
\text { F-214 }\end{array}$ & $\begin{array}{l}\text { Support to the North } \\
\text { West market and } \\
\text { bidirectional cross- } \\
\text { border flows }\end{array}$ & $\begin{array}{l}\text { Snam Rete Gas } \\
\text { S.p.A. }\end{array}$ & 2018 & Section 3 \\
\hline $\begin{array}{l}\text { Pipeline } \\
\text { including } \\
\text { CS }\end{array}$ & $\begin{array}{l}\text { TRA- } \\
\text { F-230 }\end{array}$ & $\begin{array}{l}\text { Reverse Flow Transitgas } \\
\text { Switzerland }\end{array}$ & FluxSwiss & 2018 & \\
\hline $\begin{array}{l}\text { Pipeline } \\
\text { including } \\
\text { CS }\end{array}$ & $\begin{array}{l}\text { TRA- } \\
\text { F-331 }\end{array}$ & Gascogne Midi & TIGF - GRTgaz & 2018 & $\begin{array}{l}\text { Pipeline } \\
\text { Lussagnet - } \\
\text { Barran + CS in } \\
\text { Barbaira }\end{array}$ \\
\hline $\begin{array}{l}\text { Pipeline } \\
\text { including } \\
\text { CS }\end{array}$ & $\begin{array}{l}\text { TRA- } \\
\text { F-344 }\end{array}$ & $\begin{array}{l}\text { Compressor station } \\
\text { "Herbstein" }\end{array}$ & $\begin{array}{l}\text { Open Grid Europe } \\
\text { GmbH }\end{array}$ & 2018 & Podisor - Horia \\
\hline $\begin{array}{l}\text { Pipeline } \\
\text { including } \\
\text { CS }\end{array}$ & $\begin{array}{l}\text { TRA- } \\
\text { F-344 }\end{array}$ & $\begin{array}{l}\text { Compressor station } \\
\text { "Herbstein" }\end{array}$ & $\begin{array}{l}\text { Open Grid Europe } \\
\text { GmbH }\end{array}$ & 2018 & $\begin{array}{l}\text { Compressor } \\
\text { station "Herbstein" }\end{array}$ \\
\hline $\begin{array}{l}\text { Pipeline } \\
\text { including } \\
\text { CS }\end{array}$ & $\begin{array}{l}\text { TRA- } \\
\text { F-378 }\end{array}$ & $\begin{array}{l}\text { Interconnector Greece- } \\
\text { Bulgaria (IGB Project) }\end{array}$ & ICGB a.d. & 2018 & \\
\hline $\begin{array}{l}\text { Pipeline } \\
\text { including } \\
\text { CS }\end{array}$ & $\begin{array}{l}\text { TRA- } \\
\text { F-753 }\end{array}$ & $\begin{array}{l}\text { West to East operation } \\
\text { of the IP Waidhaus }\end{array}$ & $\begin{array}{l}\text { GRTgaz } \\
\text { Deutschland GmbH }\end{array}$ & 2018 & \\
\hline $\begin{array}{l}\text { Pipeline } \\
\text { including } \\
\text { CS }\end{array}$ & $\begin{array}{l}\text { TRA- } \\
\text { F-137 }\end{array}$ & $\begin{array}{l}\text { Interconnection Bulgaria } \\
\text { - Serbia }\end{array}$ & Ministry of Energy & 2018 & Serbian territory \\
\hline $\begin{array}{l}\text { Pipeline } \\
\text { including } \\
\text { CS }\end{array}$ & $\begin{array}{l}\text { TRA- } \\
\text { F-137 }\end{array}$ & $\begin{array}{l}\text { Interconnection Bulgaria } \\
\text { - Serbia }\end{array}$ & Ministry of Energy & 2018 & Bulgarian territory \\
\hline
\end{tabular}




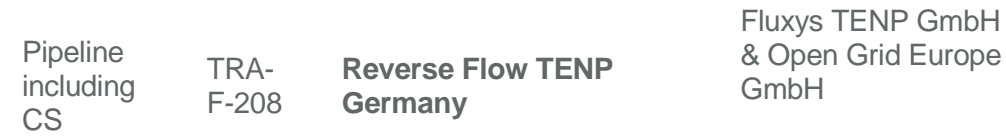

\begin{tabular}{|c|c|c|c|c|c|}
\hline $\begin{array}{l}\text { Pipeline } \\
\text { including } \\
\text { CS }\end{array}$ & $\begin{array}{l}\text { TRA- } \\
\text { F-343 }\end{array}$ & $\begin{array}{l}\text { Pipeline project } \\
\text { "Schwandorf-Finsing" }\end{array}$ & $\begin{array}{l}\text { Open Grid Europe } \\
\text { GmbH }\end{array}$ & 2018 & $\begin{array}{l}\text { Pipeline } \\
\text { "Forchheim- } \\
\text { Finsing" }\end{array}$ \\
\hline $\begin{array}{l}\text { Pipeline } \\
\text { including } \\
\text { CS }\end{array}$ & $\begin{array}{l}\text { TRA- } \\
\text { F-343 }\end{array}$ & $\begin{array}{l}\text { Pipeline project } \\
\text { "Schwandorf-Finsing" }\end{array}$ & $\begin{array}{l}\text { Open Grid Europe } \\
\text { GmbH }\end{array}$ & 2018 & $\begin{array}{l}\text { Pipeline } \\
\text { "Schwandorf- } \\
\text { Forchheim" }\end{array}$ \\
\hline $\begin{array}{l}\text { Pipeline } \\
\text { including } \\
\text { CS }\end{array}$ & $\begin{array}{l}\text { TRA- } \\
\text { F-345 }\end{array}$ & $\begin{array}{l}\text { Compressor station } \\
\text { "Werne" }\end{array}$ & $\begin{array}{l}\text { Open Grid Europe } \\
\text { GmbH }\end{array}$ & 2018 & $\begin{array}{l}\text { Compressor } \\
\text { station "Werne" }\end{array}$ \\
\hline $\begin{array}{l}\text { Pipeline } \\
\text { including } \\
\text { CS }\end{array}$ & $\begin{array}{l}\text { TRA- } \\
\text { F-051 }\end{array}$ & Trans Adriatic Pipeline & $\begin{array}{l}\text { Trans Adriatic } \\
\text { Pipeline AG }\end{array}$ & 2019 & $\begin{array}{l}\text { Main onshore } \\
\text { section }\end{array}$ \\
\hline $\begin{array}{l}\text { Pipeline } \\
\text { including } \\
\text { CS }\end{array}$ & $\begin{array}{l}\text { TRA- } \\
\text { F-051 }\end{array}$ & Trans Adriatic Pipeline & $\begin{array}{l}\text { Trans Adriatic } \\
\text { Pipeline AG }\end{array}$ & 2019 & Offshore section \\
\hline $\begin{array}{l}\text { Pipeline } \\
\text { including } \\
\text { CS }\end{array}$ & $\begin{array}{l}\text { TRA- } \\
\text { F-86 }\end{array}$ & $\begin{array}{l}\text { Interconnection } \\
\text { Croatia/Slovenia (Lučko - } \\
\text { Zabok - Rogatec) }\end{array}$ & Plinacro Ltd & 2019 & Zabok-Rogatec \\
\hline $\begin{array}{l}\text { Pipeline } \\
\text { including } \\
\text { CS }\end{array}$ & $\begin{array}{l}\text { TRA- } \\
\text { F-86 }\end{array}$ & $\begin{array}{l}\text { Interconnection } \\
\text { Croatia/Slovenia (Lučko - } \\
\text { Zabok - Rogatec) }\end{array}$ & Plinacro Ltd & 2019 & Lučko-Zabok \\
\hline $\begin{array}{l}\text { Pipeline } \\
\text { including } \\
\text { CS }\end{array}$ & $\begin{array}{l}\text { TRA- } \\
\text { F- } \\
1028\end{array}$ & $\begin{array}{l}\text { Albania - Kosovo Gas } \\
\text { Pipeline }\end{array}$ & $\begin{array}{l}\text { Min. of Energy and } \\
\text { Industry of AL \& } \\
\text { Min. of Economic } \\
\text { Development of KO }\end{array}$ & 2022 & $\begin{array}{l}\text { Fier - Lezha }(A L) \\
\text { - Prishtina }(K O)\end{array}$ \\
\hline $\begin{array}{l}\text { Pipeline } \\
\text { including } \\
\text { CS }\end{array}$ & $\begin{array}{l}\text { TRA- } \\
\text { F- } \\
1028\end{array}$ & $\begin{array}{l}\text { Albania - Kosovo Gas } \\
\text { Pipeline }\end{array}$ & $\begin{array}{l}\text { Min. of Energy and } \\
\text { Industry of AL \& } \\
\text { Min. of Economic } \\
\text { Development of KO }\end{array}$ & 2022 & $\begin{array}{l}\text { Lezha (AL) - } \\
\text { Pristina (KO) }\end{array}$ \\
\hline $\begin{array}{l}\text { Pipeline } \\
\text { including } \\
\text { CS }\end{array}$ & $\begin{array}{l}\text { TRA- } \\
\text { F-017 }\end{array}$ & $\begin{array}{l}\text { System Enhancements - } \\
\text { Eustream }\end{array}$ & eustream, a.s. & 2026 & \\
\hline $\begin{array}{l}\text { Pipeline } \\
\text { including } \\
\text { CS }\end{array}$ & $\begin{array}{l}\text { TRA- } \\
\text { F-025 }\end{array}$ & $\begin{array}{l}\text { Industrial Emissions } \\
\text { Directive (IPPC) - FID }\end{array}$ & $\begin{array}{l}\text { National Grid Gas } \\
\text { plc }\end{array}$ & Unknown & Peterborough \\
\hline $\begin{array}{l}\text { Pipeline } \\
\text { including } \\
\text { CS }\end{array}$ & $\begin{array}{l}\text { TRA- } \\
\text { F-025 }\end{array}$ & $\begin{array}{l}\text { Industrial Emissions } \\
\text { Directive (IPPC) - FID }\end{array}$ & $\begin{array}{l}\text { National Grid Gas } \\
\text { plc }\end{array}$ & Unknown & Huntingdon \\
\hline
\end{tabular}




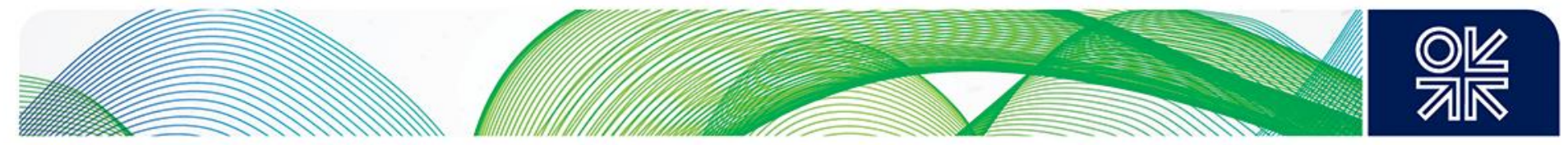

\begin{tabular}{|c|c|c|c|c|c|c|}
\hline Туре & Name & Promoter & $\begin{array}{r}\text { Commissioning } \\
\text { Year }\end{array}$ & $\begin{array}{r}\text { Project } \\
\text { Yearly } \\
\text { Volume } \\
(\mathrm{bcm} / \mathrm{y})\end{array}$ & \begin{tabular}{|r} 
Project \\
Ship \\
Size \\
(m3 \\
LNG)
\end{tabular} & $\begin{array}{r}\text { Project } \\
\text { Storage } \\
\text { Capacity } \\
\text { (m3 LNG) }\end{array}$ \\
\hline $\begin{array}{r}\text { LNG } \\
\text { Terminal }\end{array}$ & Revythoussa (2nd upgrade) & DESFA S.A. & 2017 & & 120.000 & 95.000 \\
\hline $\begin{array}{r}\text { LNG } \\
\text { Terminal }\end{array}$ & $\begin{array}{r}\text { Zeebrugge LNG Terminal - 5th } \\
\text { Tank \& 2nd Jetty }\end{array}$ & Fluxys LNG & 2019 & 3 & 0 & 180.000 \\
\hline $\begin{array}{r}\text { LNG } \\
\text { Terminal }\end{array}$ & Musel LNG terminal & $\begin{array}{r}\text { Enagás Transporte, } \\
\text { S.A.U. }\end{array}$ & 2026 & 7 & 7266.000 & 300.000 \\
\hline
\end{tabular}



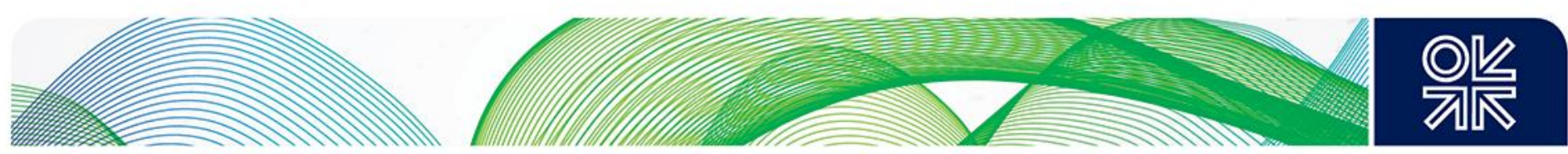

\section{Bibliography}

ACER (2016): ACER/CEER 2016 Market Monitoring Report, 09 Nov 2016

GIE (2016): GIE System Development Map 2015 - 2016. Available at:

http://www.gie.eu/index.php/maps-data/system-development-map

GLE (2016): GIE LNG Map 2016. Available at: http://www.gie.eu/index.php/maps-data/lng-map

GSE (2016) GIE Storage Map 2016. Available at: http://www.gie.eu/index.php/maps-data/gsestorage-map

ENTSOG - TYNDP (2017): ENTSOG Ten Year Network Development Plan 2017 - Main Report. Available at: http://www.entsog.eu/publications/tyndp\#ENTSOG-TEN-YEAR-NETWORKDEVELOPMENT-PLAN-2017

EWI/EUCERS (2016): Hecking, H., Vatansever, A., Schulte, S., Raszewski, S.: Options for Gas Supply Diversification for the EU and Germany in the next Two Decades. London und Cologne.

Henderson and Pirani (2014): The Russian Gas Matrix - How Markets Are Driving Change, Oxford University Press

Interfax (2015): НКРЭКУ установила "Укртрансгазу" тарифы на транзит газа для точек входа и выхода. Interfax. Available at: http://interfax.com.ua/news/economic/314958.html France Oks

Lochner and Bothe (2007). From Russia with Gas - An Analysis of the Nord Stream pipeline's impact on the European Gas transmission system with the TIGER model, EWI Working Paper 07.02.

Lochner (2012), The Economics of Natural Gas Infrastructure Investments - Theory and Model-based Analysis for Europe. Dissertation, Universität zu Köln.

Naturalgasworld (2016): Strategic New Pipe'. Natural Gas World. May $20^{\text {th }} 2016$. Available at: http://www.naturalgasworld.com/france-clears-grtgaz-to-build-new-pipe-29672

OIES, EWI (2016): Petrovich, B., Rogers, H., Hecking, H., Weiser, F.: European gas grid through the eye of the TIGER: investigating bottlenecks in pipeline flows by modelling history. OIES, EWI. September 2016, https://www.oxfordenergy.org/publications/european-gas-grid-eye-tigerinvestigating-bottlenecks-pipeline-flows-modelling-history/

Petrovich (2013), European gas hubs - how strong is price correlation?, OIES, https://www.oxfordenergy.org/publications/european-gas-hubs-how-strong-is-price-correlation/

Petrovich (2014), European gas hubs price correlation - barriers to convergence, OIES, https://www.oxfordenergy.org/publications/european-gas-hubs-price-correlation-barriers-toconvergence/

Petrovich (2015), The cost of price de-linkages between European gas hubs, OIES, https://www.oxfordenergy.org/publications/the-cost-of-price-de-linkages-between-european-gas-hubs/

Rogers (2015), The Impact of Lower Gas and Oil Prices on Global Gas and LNG Markets, OIES, https://www.oxfordenergy.org/publications/the-impact-of-lower-gas-and-oil-prices-on-global-gas-andIng-markets/

Rogers (2016), Asian LNG Deman: Key Drivers and Outlook, OIES, https://www.oxfordenergy.org/publications/asian-Ing-demand-key-drivers-outlook/ 

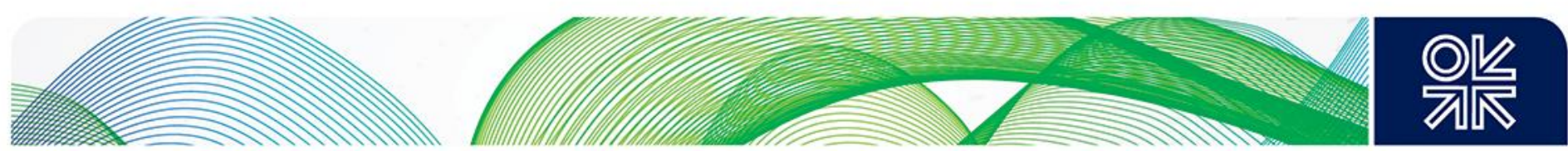

\section{Glossary}

ACER: Agency for the Cooperation of Energy Regulators

Bcm: One billion cubic metres.

Bcma: billion cubic metres per annum

Capacity hoarding: an action aiming to prevent access to capacity available on the transport network, deemed as an abuse of dominant position.

CEGH: Central European Gas Hub. For the sake of easy comparison to previous papers by OIES we simply name the Austrian gas hub CEGH. However, it should be noted that strictly speaking CEGH is only the name of the exchange operator now, not the name of the trading hub/point, which is VTP. More specifically, with the launch of the new Austrian Gas Act in January 2013, trading within the Austrian market changed from a flange-based system to an Entry/Exit regime and trading activities began to be centralized at the Virtual Trading Point (VTP), which is operated by CEGH. The market operator CEGH offers trading activities and services for different markets: CEGH OTC (over-thecounter) Market, CEGH Gas Exchange Spot Market of Wiener Boerse (Day-Ahead and Within-Day Market), CEGH Gas Exchange Futures Market of Wiener Boerse (Front Month, Quarter, Season, Year), CEGH Czech Gas Exchange in cooperation with PXE (Spot and Futures Market).

CMP: Congestion management procedures

Congestion Management Procedures (CMP) Guidelines: Commission Decision of 24 August 2012 on amending Annex I to Regulation (EC) No 715/2009 of the European Parliament and of the Council on conditions for access to the natural gas transmission networks (2012/490/EU), OJL 213/16, 28.8.2012

Day ahead (DA) contract/product: Contract for the purchase or sale of gas to be delivered the day after the trading date.

Entry-exit system A system where gas can be traded independently of its location in the pipeline system, with the possibility for network users to book entry and exit capacity independently, creating gas transport through zones instead of along contractual paths.

ENTSOG: Association of European gas TSOs.

EUGAL: European Gas Pipeline Link.

FID: Final Investment Decision.

GIPL: Gas Interconnection Poland-Lithuania.

GSL: Gaspool, gas hub based in Germany.

GTM (Gas Target Model): Conceptual model for the single European gas markets originally developed by CEER in 2011, and updated in 2015.

GWh: A unit of energy equivalent to a Gigawatt of power for the duration of one hour.

Hub (gas hub): A virtual or physical location within the grid where the exchange of gas volumes takes place. In fact, a gas hub is a market for gas, where the commodity is traded on a standardized basis between market participants. In this paper each hub represents a different price area.

IEA: International Energy Agency.

Interconnection Point (IP): Means a location, whether it is physical or virtual, between two or more EU Member States as well as between two adjacent entry-exit-systems within the same Member State, where the pipeline systems of the two adjacent Member States or entry exit systems join.

kWh: A unit of energy equivalent to a Kilowatt of power for the duration of one hour. 

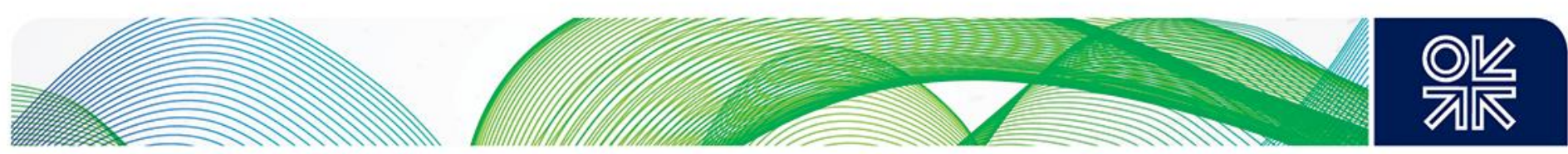

mcm: One million cubic metres.

MEGAL Pipeline: The MEGAL pipeline ("Mittel-Europäische-Gasleitung") is a major natural gas pipeline system in southern Germany. It transports natural gas from the Czech-German and Austrian-German borders to the German-French border.

MWh: A unit of energy equivalent to a Megawatt of power for the duration of one hour.

NBP: National Balancing Point, gas hub based in Great Britain.

NCG: Net Connect Germany, gas hub based in Germany.

NEL Pipeline: Northern European natural gas pipeline.

OPAL: The OPAL (Ostsee-Pipeline-Anbindungsleitung) is a natural gas pipeline in Germany alongside the German eastern border. It is one of two projected pipelines connecting the Nord Stream pipeline to the existing pipeline grid in Middle and Western Europe, the other one being the NEL pipeline.

OTC (over the counter) trades: Bilateral non-regulated trade involving standardized physical and financial deals. Such trades are based on standard agreements defining the point of delivery for gas along with other technical and legal terms. They can be for standard volumes of clip sizes of gas and multiples thereof.

PEGN: Point d'Echange de Gaz Nord (Peg North), gas hub based in the North of France, coinciding with the GRTgaz network.

PEGS: Point d'Echange de Gaz Sud (Peg South), gas hub based in the South of France. On April 1, 2015, the PEG TIGF and PEG Sud hubs merged to form a single gas hub to be named Trading Region South (TRS).

PEGT: Point d'Echange de Gaz TIGF (Peg South), gas hub based in the South of France. On April 1, 2015, the PEG TIGF and PEG Sud hubs merged to form a single gas hub to be named Trading Region South (TRS).

Price correlation: When prices move closely in parallel over time.

Price de-linkage: Period of low price correlation.

PSV: Punto di Scambio Virtuale, the Italian gas hub.

TAP: Trans Adriatic Pipeline. A pipeline project to transport natural gas, starting from Greece via Albania and the Adriatic Sea to Italy and further to Western Europe.

TENP: The gas pipeline that runs across German territory from Bocholtz, at the Dutch border, to the Swiss border, close to Wallbach, where it joins Transitgas.

TIGER Model: The European supply-demand transmission model TIGER was developed by EWI at the University of Cologne; it works using as inputs demand, production capacities of major gas suppliers, European domestic production, information on long term contracts, transmission tariffs data and gives as an output a pattern of gas physical flows within Europe. TIGER is a cost minimizing model: the whole system is optimized with regard to the cost for the gas supply, subject to several infrastructure constraints, for example capacity limits of pipelines or injection/withdrawal storage curves. For a technical model description, please refer to Lochner (2012).

Transitgas: The gas pipeline that crosses Switzerland from Wallbach at the German border to Passo Gries (Gries Pass) at the Italian border. At Wallbach Transitgas joins the Trans Europa Naturgas Pipeline (TENP), at Passo Gries it joins the Italian network.

Transmission System Operator (TSO): the company responsible for transmission system operation. Some countries have one gas TSO, others have several TSOs. 

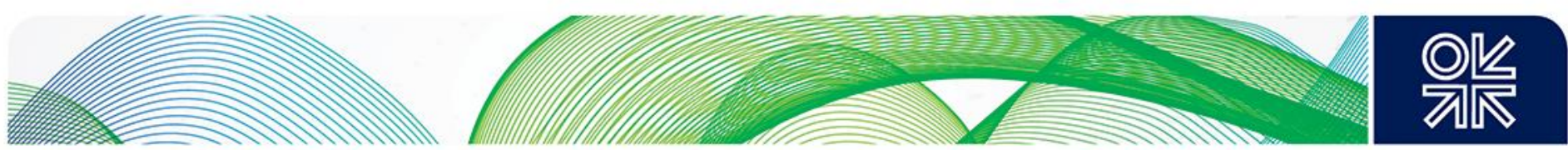

TRS: Trading Region South, French hub located in the South of France. On April 1, 2015, the PEG TIGF and PEG Sud hubs merged to form a single gas hub to be named Trading Region South (TRS).

TTF: Title Transfer Facility, gas hub based in the Netherlands.

VTP: Virtual Trading Point

WAG Pipeline: West-Austria-Gaspipeline 